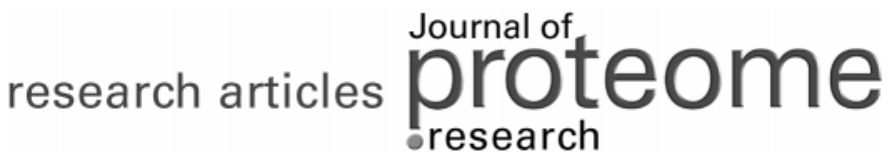

\section{Application of Fluorescence Difference Gel Electrophoresis Technology in Searching for Protein Biomarkers in Chick Myopia}

\author{
Thomas C. Lam, ${ }^{\dagger}$ King-Kit Li, ${ }^{\dagger}$ Samuel C. L. Lo, ${ }^{*, \neq}$ Jeremy A. Guggenheim, ${ }^{\S}$ and Chi Ho To ${ }^{*, \dagger}$ \\ Laboratory of Experimental Optometry, Centre for Myopia Research, School of Optometry, The Hong Kong \\ Polytechnic University, Hung Hom, Kowloon, HKSAR, The Proteomic Task Force, Department of Applied \\ Biology and Chemical Technology, The Hong Kong Polytechnic University, Kowloon, HKSAR and The State Key \\ Laboratory of Chinese Medicine and Molecular Pharmacology, Shenzhen, China, and Department of \\ Optometry \& Vision Sciences, Cardiff University, Redwood Building, King Edward VII Avenue, Cardiff, U.K.
}

Received February 27, 2007

\begin{abstract}
The lens-induced myopia (LIM) in response to concave lens (negative lens) is a well established animal model for studying myopia development. However, the exact visual and neurochemical signaling mechanisms involving myopic eye growth are yet to be elucidated. The feasibility of applying a novel two-dimensional fluorescence difference gel electrophoresis technique for global protein profilings and a search for differential protein expressions in LIM were explored in the present study. Two-dimensional polyacrylamide gel electrophoresis was performed employing a "minimal Lysine labeling" approach and a reverse CyeDye experimental protocol using retinal tissue from chicks. The retinal protein profiles between myopic and control eyes were found to be very similar. More than a thousand protein spots could be detected on a 2D gel. Sixteen and ten protein spots were found to be up-regulated and downregulated respectively in the myopic eyes according to our preset criteria with the inclusion of an internal pool standard. About $65 \%$ of those filtered spots could be successfully identified by peptide mass fingerprinting by matrix-assisted laser desorption ionization-time-of-flight mass spectrometry . Most of the differentially expressed proteins were found to be related to cytoskeletal or oxidative functions. According to the prediction of subcellular locations, most of them (about $84 \%$ ) were classified as cytoplasmic proteins. The cellular functions for those differentially expressed proteins were reported and their possible involvements in the compensated eye growth were discussed. We have optimized a workable protocol for the study of the differential retinal protein expressions in the LIM using 2DDIGE approach which was shown to have a number of advantages over the traditional 2D electrophoresis technique.
\end{abstract}

Keywords: Two-dimensional gel electrophoresis $\bullet$ chick $\bullet$ myopia $\bullet$ proteomics $\bullet$ DIGE $\bullet$ retina $\bullet$ mass spectrometry

\section{Introduction}

Myopia (or shortsightedness) describes an eye which has grown too long for its optical focusing system. Myopia problem is often regarded as a simple refractive condition that causes inconvenience in our daily life. However, it may cause severe sight-threatening retinal degeneration that carries significant financial implications and health concerns for both the individuals and community. High myopia is known to be associated with secondary ocular diseases such as cataract, ${ }^{1}$ posterior

* To whom correspondence should be addressed. (Prof. Chi-Ho To) E-mail: sochto@inet.polyu.edu.hk. Tel: (852) 2766 6102. Fax: (852) 2764 6051. Address: School of Optometry, the Hong Kong Polytechnic University, Hung Hom, Kowloon, Hong Kong SAR, China; (Prof. Samuel Chun-Lap Lo) E-mail: bcsamlo@inet.polyu.edu.hk. Tel: (852) 2766 6686. Fax: (852) 2364 9932. Address: Department of Applied Biology and Chemical Technology, the Hong Kong Polytechnic University, Hung Hom, Kowloon, Hong Kong SAR, China. (Both authors contributed equally to this work.)

† School of Optometry, The Hong Kong Polytechnic University.

‡ Department of Applied Biology and Chemical Technology, The Hong Kong Polytechnic University.

$\S$ Cardiff University. vitreous detachment, ${ }^{2}$ glaucoma, ${ }^{3}$ retinal detachment, ${ }^{4,5}$ and macular degeneration. ${ }^{6}$ These conditions can lead to permanent visual loss and blindness. ${ }^{7}$ More importantly, surveying data have revealed a global escalating prevalence of myopia among different populations ${ }^{8-12}$ and across different age groups. ${ }^{13,14}$ It is estimated that the number of myopes in the world will grow from 1.6 billion presently to a staggering 2.5 billion by 2020 (data obtained from The Vision Cooperative Research Centre. www.visioncrc.org). With the increasing prevalence of myopia, a higher prevalence of its related complications will be anticipated in the near future.

Animal studies, initially in monkeys ${ }^{15}$ and chicks, ${ }^{16}$ have suggested that the ocular growth is regulated by visual inputs. It has been shown that the retina is capable of detecting the direction of optical defocus locally. ${ }^{14}$ Isolating the inputs from higher brain by blockage of ganglion cell signal ${ }^{17}$ or optic nerve section ${ }^{18}$ does not prevent the regulatory eye growth. Furthermore, the eye is capable of compensating localized defocus with differential regional growth ${ }^{19}$ in the eye. Therefore, the 
myopic growth is signalled locally via cascades of reactions that run from the retina to the sclera. However, the molecular events that trigger myopic growth are still poorly understood. The hope to unravel the pathogenesis of myopia may lie in our understanding of the protein regulations and their interactions in response to the myopic growth.

Two-dimensional polyacrylamide gel electrophoresis (2-D PAGE) is currently the key technique for profiling thousands of proteins of a given proteome simultaneously. Recent advances in proteomic instrumentation and bioinformatics have led to significant biological discoveries in many diseases. ${ }^{20-24}$ Early applications of 2-D PAGE have been attempted to study subclasses of retinal polypeptides modifications in Drosophila eyes $^{25}$ and to study the changes of groups of proteins in mutated chick retina. ${ }^{26}$ Recently, we have established the first proteome database for chick (gallus gallus) retina. In particular, we have devised a working protocol and successfully applied the technique in the study of retinal protein changes during normal postnatal ocular growth in young growing chicks. ${ }^{27}$ Despite the continuous advances in 2D PAGE technique, including better solubility of the new lysis buffer, higher resolution IEF with IPGs and improved detection agents, the gel-to-gel variations are considerable and reliable quantitative comparisons between gels remain a major challenge in proteomic study nowadays.

A novel two-dimensional fluorescence difference gel electrophoresis (2-D DIGE) technique, first described by Unlu et al. and later marketed by Amersham Bioscience as Ettan DIGE, ${ }^{14,28}$ targets to solve these problems by providing a highly reliable and quantitative dimension to the 2-D PAGE technique. In the DIGE approach, two to three protein extracts can be individually prelabeled by different spectrally resolvable, sizeand charge-matched fluorescent CyDye DIGE fluors. The labeled proteins are then mixed and separated by isoelectric focusing in the first dimension and molecular size in the second dimension similar to the traditional 2-D PAGE technique but on a single gel. Images of the protein profile on the gel are acquired sequentially using lasers of appropriate excitation wavelengths. Since the proteins from different extracts are separated under identical experimental conditions within the same gel, comparisons of different protein profiles are therefore free of gel running variations. The ratio of the differentially expressed protein spots among different samples are normalized and derived by software to further provide quantitative analysis.

Myopia is thought to be a multifactorial disease which possibly involves a number of proteins regulations that lead to an accelerated growth of the eyeballs. In the present work, we studied the capability of the DIGE technology in identifying differential protein expressions in the emmetropization of chick retina. The experimental benefits of DIGE technology comparing to the traditional 2-D PAGE technique were also discussed.

\section{Materials and Methods}

Care and use of the animals in these experiments was in accordance with the ARVO resolution on the Use of Animals in Research and in compliance with university guidelines setforth by the Animal Subjects Research Ethnic Subcommittee (ASEC). The details of the rearing of chicks and tissues collection have been described in our previous study. ${ }^{27}$ Briefly, newly hatched white leghorn chicks were kept in temperaturecontrolled brooders on a 12/12 h light/dark cycle, and fed food and water ad libitum. Chicks were sacrificed by $\mathrm{CO}_{2}$ overdose after 7 days lens treatment. After removing the extraocular tissues, the eyes were hemisected near to the equator. The anterior segment and vitreous were discarded. The retinal layer was carefully peeled off from the posterior hemisphere and was immediately frozen before further analysis. All chemicals used were at least at purity of HPLC grade. Reagents for 2-DE and silver staining were purchased from BioRad (USA), Amersham Biosciences (China), and Sigma-Aldrich (USA).

Retinal Samples. Two pairs of retinal tissues from age matched chicks after 7 days, $-10 \mathrm{D}$ monocular lens wear were isolated. Refractive errors after hatching and before dissection were measured using a streak retinoscope. The resultant equivalent sphere $($ S.E. $=$ spherical power $+1 / 2$ cylindrical power) was calculated on the basis of the two powers along the vertical and horizontal meridians. The retinal proteins were extracted with a DIGE compatible lysis buffer (7 M urea, $2 \mathrm{M}$ thiourea, $30 \mathrm{mM}$ tris, $2 \%$ CHAPS, $1 \%$ ASB14) in which DTT, Biolyte, primary amines, or thiols were omitted during the homogenization stage as they may affect the subsequent CyDyes labeling. The protein concentrations of the four retinal extracts were determined by the 2-D Quant Kit (Amersham Biosciences).

Proteins Labeling with CyDyes. Lysine labeling protocol which is referred to as "minimal labeling" was utilized in this study. Each dye $(25 \mathrm{nmol})$ was reconstituted with $25 \mu \mathrm{L}$ anhydrous $N, N$-dimethylformamide (Aldrich chemical co.) and $1000 \mathrm{pmol} / \mu \mathrm{l}$ stock dye which is stable at $-20^{\circ} \mathrm{C}$ for at least 2 months time according to the manufacturer'xads recommendation. The stock dye was further diluted to $400 \mathrm{pmol} / \mu \mathrm{l}$. It formed the working dye solution for immediate use for the labeling reaction. Tris $\mathrm{HCl}(50 \mathrm{mM})$ was used to adjust the $\mathrm{pH}$ of the samples to about 8.5 which is the optimal $\mathrm{pH}$ for cyanine CyDyes labeling. The soluble retinal proteins were then labeled individually with dyes Cy3 and Cy5 while the pooled retinal proteins from all samples were labeled with Cy2. A $50 \mu \mathrm{g}$ portion (about $8-9 \mu \mathrm{L}$ ) of each soluble protein extract and the pooled sample $(12.5 \mu \mathrm{g} \times 4)$ was mixed with $1 \mu \mathrm{L}$ of working Cy2, Cy3, or Cy5 and incubated on ice for $30 \mathrm{~min}$ in the dark. The labeling reactions were quenched with $1 \mu \mathrm{L}$ of $10 \mathrm{mM}$ lysine and incubated further on ice for $10 \mathrm{~min}$. Differentially labeled samples were mixed with the pooled Cy2-labeled extracts, and an equal volume of lysis buffer with $2 \%$ (w/v) DTT and $0.4 \%(\mathrm{v} / \mathrm{v})$ Biolyte was added to reduce proteins at room temperature for $10 \mathrm{~min}$. The final volume for all preparations was adjusted to a total of $300 \mu \mathrm{L}$ with rehydration buffer $(7 \mathrm{M}$ urea, $2 \mathrm{M}$ thiourea, $0.2 \%$ Biolyte, $1 \%$ DTT, $2 \%$ CHAPS, $1 \%$ ASB14, and a trace amount of bromophenol blue).

The DIGE technology is a recent technique and the labeling property of CyDyes for retinal tissue was yet to be characterized. To validate the application of DIGE technique to our samples, a reciprocal labeling experiment in which both the treatment and control groups were labeled by Cy3 and Cy5 was conducted to account for any preferential protein labeling by CyDyes. The labeling protocols for all 2-D gels prior to electrophoresis were shown in Table 1.

Two-Dimensional Gel Electrophoresis. To obtain better resolution, $17 \mathrm{~cm}$ IPG strips of pH 5-8 (BioRad) were employed in the first dimension to study the area where most of the soluble retinal proteins were located as found in our pilot study. A $150 \mu \mathrm{g}$ portion of pooled labeled proteins was focused for a total of $30000 \mathrm{Vh}$ at a constant temperature $\left(20^{\circ} \mathrm{C}\right)$ under linear voltage ramp after an active IPG rehydration at $50 \mathrm{~V}$ in 
Table 1. The Experimental Design of CyDyes Minimal Labeling for Each Retinal Sample in the DIGE Studya

\begin{tabular}{llll}
\hline $\begin{array}{l}\text { gel } \\
\text { no. }\end{array}$ & \multicolumn{1}{c}{ Cy3 } & \multicolumn{1}{c}{ Cy5 } & \multicolumn{1}{c}{ Cy2 (pool control) } \\
\hline gel 1 & $\begin{array}{l}\text { no. } 1 \text { treated } \\
(50 \mu \mathrm{g})\end{array}$ & $\begin{array}{l}\text { no. } 1 \text { control } \\
(50 \mu \mathrm{g})\end{array}$ & $\begin{array}{l}\text { no. } 1 \text { and no. } 2 \text { treated and control } \\
(25 \mu \mathrm{g} \text { no. } 1 \text { and } 25 \mu \mathrm{g} \text { no. })\end{array}$ \\
gel 2 & $\begin{array}{l}\text { no. } 2 \text { treated } \\
(50 \mu \mathrm{g})\end{array}$ & $\begin{array}{l}\text { no. } 2 \text { control } \\
(50 \mu \mathrm{g})\end{array}$ & $\begin{array}{l}\text { no. } 1 \text { and no. } 2 \text { treated and control } \\
(25 \mu \mathrm{g} \text { no. } 1 \text { and } 25 \mu \mathrm{g} \text { no. })\end{array}$ \\
gel 3 & $\begin{array}{l}\text { no. } 1 \mathrm{control} \\
(50 \mu \mathrm{g})\end{array}$ & $\begin{array}{l}\text { no. } 1 \text { treated } \\
(50 \mu \mathrm{g})\end{array}$ & $\begin{array}{l}\text { no. } 1 \text { and no. } 2 \text { treated and control } \\
(25 \mu \mathrm{g} \text { no. } 1 \text { and } 25 \mu \mathrm{g} \text { no. })\end{array}$ \\
gel 4 & $\begin{array}{l}\text { no. } 2 \text { control } \\
(50 \mu \mathrm{g})\end{array}$ & $\begin{array}{l}\text { no. } 2 \text { treated } \\
(50 \mu \mathrm{g})\end{array}$ & $\begin{array}{l}\text { no. } 1 \text { and no. } 2 \text { treated and control } \\
(25 \mu \mathrm{g} \text { no. } 1 \text { and } 25 \mu \mathrm{g} \text { no. })\end{array}$ \\
& & &
\end{tabular}

${ }^{a}$ A total of $150 \mu \mathrm{g}$ of labeled proteins were loaded on each gel for $2 \mathrm{D}$ electrophoresis; no. 1 and no. 2 represented two individual chicks.

a PROTEAN IEF cell (BioRad). Following focusing, each IPG strip was placed in the equilibrium buffer containing $0.5 \%$ DTT first and in another buffer in which the DTT was replaced by $4.5 \%$ iodoacetamide. The second dimension was carried out in a Hoeffer SE600 $(16 \times 18 \mathrm{~cm})$ vertical tank (Amersham Biosciences) at constant $30 \mathrm{~mA} /$ gel. The polyacrylamide gels (12\%) were prepared with low fluorescent Pyrex glass plates in order to minimize the background fluorescence and maximize the signal-to-noise ratio during the image scan. All electrophoresis procedures were performed in dim light or in the dark.

After the fluorescent image scanning, a second phase of electrophoresis immediately followed. All gels were returned to the SE600 tank for a further second dimension separation run at $15 \mathrm{~mA}$ /gel overnight. The electrophoresis process was stopped at the same time, and the images were scanned again for a better visualization of protein profiles at higher molecular weight region.

Protein Profiles Detection. After 2DE, the gels were scanned in situ with the glass plates according to the gel alignment guides provided using a Typhoon 9400 Variable Mode Imager (Amersham Biosciences). All laser power adjustment and image acquisition were done by the bundle Typhoon Scanner Control program. The Cy3 gel images were scanned at an excitation wavelength of $532 \mathrm{~nm}$ (green laser) and at an emission wavelength of $580 \mathrm{~nm} / \mathrm{BP} 40$ (maxima/bandwidth). The Cy5 gel images were scanned at an excitation wavelength of 633 $\mathrm{nm}$ (red laser) and at an emission wavelength of $670 \mathrm{~nm} / \mathrm{BP}$ $30 \mathrm{~nm}$ while the Cy2 gel images were scanned at an excitation wavelength of $488 \mathrm{~nm}$ and at an emission wavelength of 520 $\mathrm{nm} / \mathrm{BP}$ 40. The BP emission filters were used to minimize possible cross-talk between different fluorescence channels. Although an "auto link mode" for a single pass scan for all three channels was available, the scanning of gel with different lasers was carried out individually to ensure a better sensitivity. Edge illumination was used and the prescan laser power adjustment was performed with $1000 \mu \mathrm{m}$ pixel size to allow full utilization of the image dynamic range before saturation. The resolution for final quantitative analytical scans was set at $100 \mu \mathrm{m}$, and the final laser powers for Cy3, Cy5, and Cy2 were set as 520 PMT, 488 PMT, and 500 PMT, respectively.

Image Analysis. The scanned gels were saved as modified 16-bit tiff format as *.gel format which gave good gray-scale representation for the wide dynamic range of protein spots. Prior to analysis, all gel images were cropped to identical size by removing areas extraneous to the proteins spots by the ImageQuant, version 5.0 (Amersham Biosciences) and they were transferred to the DeCyder Differential Analysis Software, version 6.0 (Amersham Biosciences) for further analysis.

Gel specific spot exclusion parameters were first determined to remove artifacts (such as dust particles, scratches, and protein streaks). A batch processor without user intervention was later implemented to perform fully automated background subtraction, spot codetection, quantitation, and matching according to the experimental design in Table 1 . The standardized spot volume (the sum of pixel values within a detected spot boundary) was calculated as the ratio between the absolute volume of the individual spot and the total volume of the gel. The pooled gel images (Cy 2) on each gel were intrinsically linked to the treatment and control gel images (Cy3 and Cy5) within the same gels and across the pooled images of other gels. A DeCyder differential in-gel analysis (DIA) module was performed for image analysis between samples within the same gel while a DeCyder biological variation analysis (BVA) module was performed for pairwise image analysis among multiple gels. Ratios of differentially expressed proteins were shown as "fold" changes between the treated myopic eyes and the control eyes. An increase of protein abundance in the treated eye was expressed as a positive value while a negative value denoted a decrease in the protein abundance. Protein spot can be normalized using the corresponding spot on the pooled internal standard on every gel. Student's $t$-test on logged ratios could be used to compare the average spot volume and significant differences of protein abundance for all detectable pairs between the treatment and control groups. The workflow was described in Figure 1. To avoid any preferential CyDyes labeling of particular protein spots, which may bias the differential protein expressions, images of the reciprocal dyes labeling of gel 1 and gel 3 were exported and converted as tiff format for overlay comparisons with the ImageMaster 5 gel analysis software. The differential expressions could be observed visually by using different color channels for the treatment and control groups.

Protein Identification and Mass Spectrometry. To allow MS protein identifications of spots of interest, preparative traditional 2-D PAGE gels were rerun as individual gels for the four retinal samples. Extracts of pooled proteins $(100 \mu \mathrm{g})$ from four retinal samples were separated on $17 \mathrm{~cm}$ IPG strips of $\mathrm{pH} 5-8$ in the first dimension. The buffers and running conditions were based on the DIGE protocol. The 2-D gels were stained with MS compatible silver stain and the protein profiles were compared with the DIGE images in the ImageMaster 5 gel analysis software to identify the differentially expressed proteins. Gel spots were then excised manually for in-gel trypsin digestion, and MALDI-TOF MS was performed as described in our previous study. ${ }^{27}$ In brief, the analytes were cocrystallized with HCCA matrix on AnchorChip (400 or $600 \mu \mathrm{m}$ spot size) (Bruker Daltonics, Germany), a prestructured MALDI sample support which was proven to enhance the sensitivity of detection. ${ }^{29,30}$ Mass spectra were acquired using a Bruker Autoflex MALDI-TOF mass spectrometer under the positive ion reflectron mode. No digital smoothing was applied to the peaks generated and MS peaks were deisotoped. Nonlinear external calibration was done with a calibrant mixture containing angiotensin II ( $m / z$ 1046.5418), angiotensin I $(m / z$ 1296.6848), substance $\mathrm{P}(\mathrm{m} / \mathrm{z}$ 1347.7354), bombesin $(\mathrm{m} / \mathrm{z}$ 1619.8223), АCTH (fragment 1-17, $m / z$ 2093.0862), and ACTH (fragment 18-39, $m / z$ 2465.1983). The spectra were further calibrated internally against the autoproteolytic trypsin fragments of $\mathrm{m} / \mathrm{z} 842.509$ and $m / z 2211.104$. The resulting peak lists from 800 to 3000 $\mathrm{m} / \mathrm{z}$ for all samples were generated by the FlexAnalysis 2.0 software (Bruker Daltonik, Germany). After removing all known contaminant peaks of trypsin digests and keratins, peaks with $S / N$ ratio higher than 8 were searched against the NCBInr 


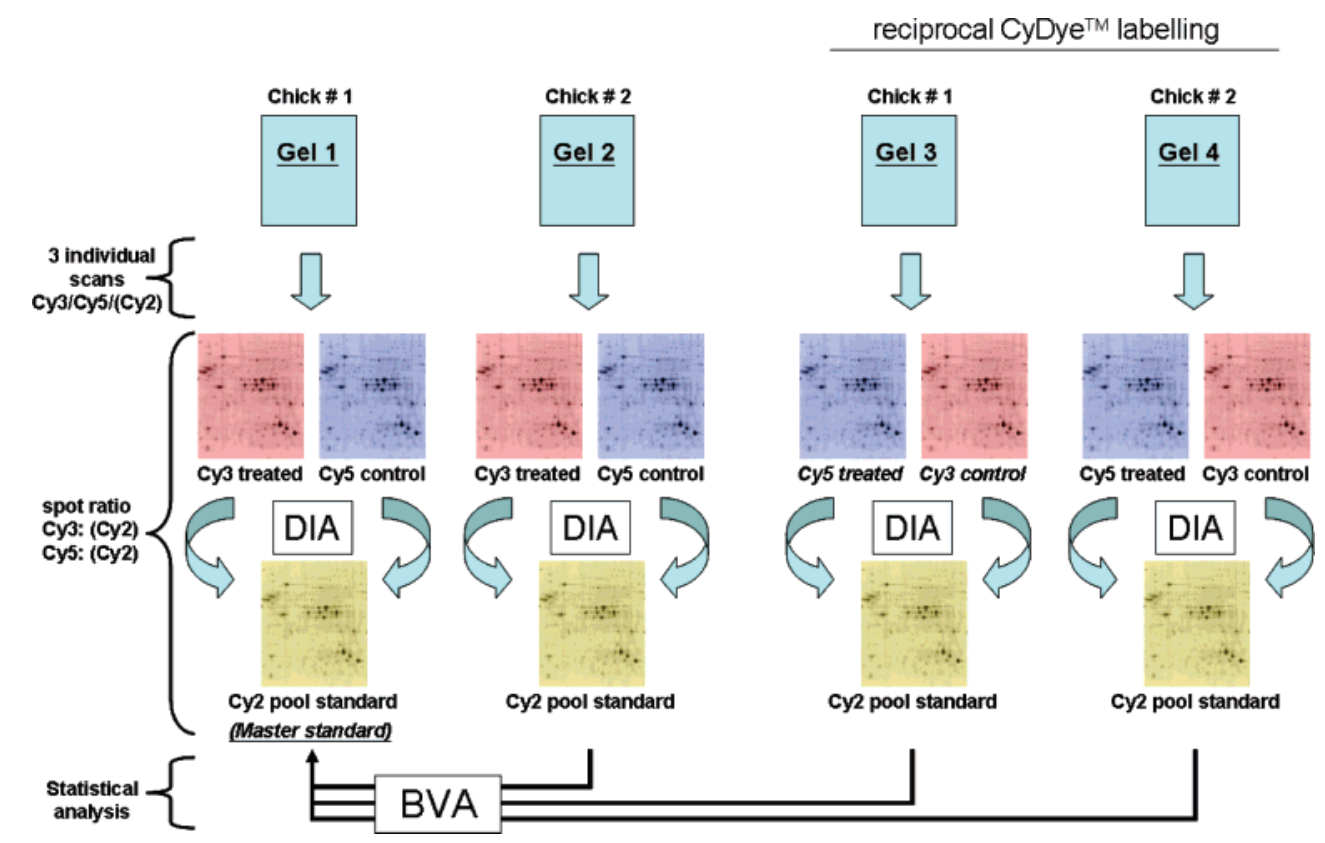

Figure 1. A schematic diagram outlines the DIGE experimental setup and data analysis by DeCyder differential analysis software. The three image profiles of pre-labeled proteins were individually scanned at their excitation wavelengths by a fluorescence scanner (Typhoon 9400 Variable Mode Imager). Detection and quantitation of protein spots (expressed as a ratio relative to the internal pool standard) were performed by co-detection algorithms in the DIA module in the same gels. The spot profiles across multiple gels were compared by matching all protein spots among different pool standards to the master standard (in which the highest number of protein spot was detected) using the BVA module.

sequence database, NCBInr 20070120 (4 462937 sequences; 1534242322 residues) and SwissProt database, 51.5 (254 609 sequences; 93000223 residues) via the Mascot search engine online (http://www.matrixscience.com) or through the $\mathrm{m} / \mathrm{z}$ software, Biotools 2.0 (Bruker Daltonik, Germany).

For database entry, we restricted the taxonomy to Metazoa (animals) and allowed a maximum of one missed cleavage. The protonated molecule ion "MH+" and "monoisotopic" were defined for the peak mass data input. The potential chemical modifications of a peptide such as the alkylation of a cysteine [carbamidomethyl (C)] and the oxidation of a methionine residue [oxidation $(\mathrm{M})$ ] were also considered in the search. For all mass lists, the peptide tolerance/error was at most $100 \mathrm{ppm}$, and no restriction was applied for both protein isoelectric point and molecular weight. A successful PMF was reported when a significant match $(P<0.01)$ was acquired for each particular spot according to the probability based Mowse score in the Mascot search engine. When there was more than one significant hit returned, the protein matched to "gallus" taxonomy was chosen. Otherwise, proteins with the highest score were reported if no match to "gallus" was found. Biological variant of protein isoforms with the same score achieved were also listed. All identified proteins had to be with more than four peptides matched and sequence coverage of more than $10 \%$.

\section{Results}

Refractive Changes in Chick Eyes. Both animals developed significant myopia after the treatment period. The final refractive errors (spherical equivalent) of the myopic eyes were -10.5 $\mathrm{D}$ and $-11.5 \mathrm{D}$, respectively, in the two chicks while only mild hyperopia was found in their fellow control eyes. The result was similar to the findings of an earlier study. ${ }^{31}$

Protein Profiles of CyDyes Labeled Retinal Proteins. According to the experimental design as described in Figure 1, an overview of the fluorescent DIGE images of two individual animals (gel 1 for chick no. 1, while gel 2 for chick no. 2) were shown in Figure 2. The fluorescent images generated by the typhoon system were relatively simple and readily comparable to the traditional silver or coomassie stained gels. All three passes of fluorescent scans with sufficient resolution for DIGE analysis could be obtained within $30 \mathrm{~min}$. There were three individual images captured from each gel (with $50 \mu$ g protein). The Cy3 images represented the retinal profiles of the treatment (defocus) eyes, and the Cy5 images represented retinal profiles of the control (normal) eyes. The Cy2 images were the pooled standard containing an equal amount of protein from each sample and therefore represented an average of all the samples to be compared.

The DIGE approach allowed co-running of different samples in the same gel which have produced highly repeatable and consistent gel images of the six analytes electrophoresed by 2-D PAGE. It could be observed from Figure 2 that not only the protein spots but also the streaks or gel distortions due to the experimental artifacts were almost identical among the three fluorescent images of the same gel. In addition, the protein profiles of the reciprocal CyDye labeling were also very similar to the above gel images (data not shown), which suggested there was minimal preferential labeling of CyDyes.

Image Analysis by DeCyder DIA. The protein co-detection of the three different CyDye labeled images in each gel was first analyzed by the DIA module. To perform reliable quantification, there is a built-in normalization function to compensate for experimental variations, such as differences in laser power, fluorescence labeling, and sample loading. The normalized abundances of all protein spots were obtained by comparing against the pooled standard (Cy3/Cy2 versus Cy5/Cy2). They were further compared between the treatment and the 


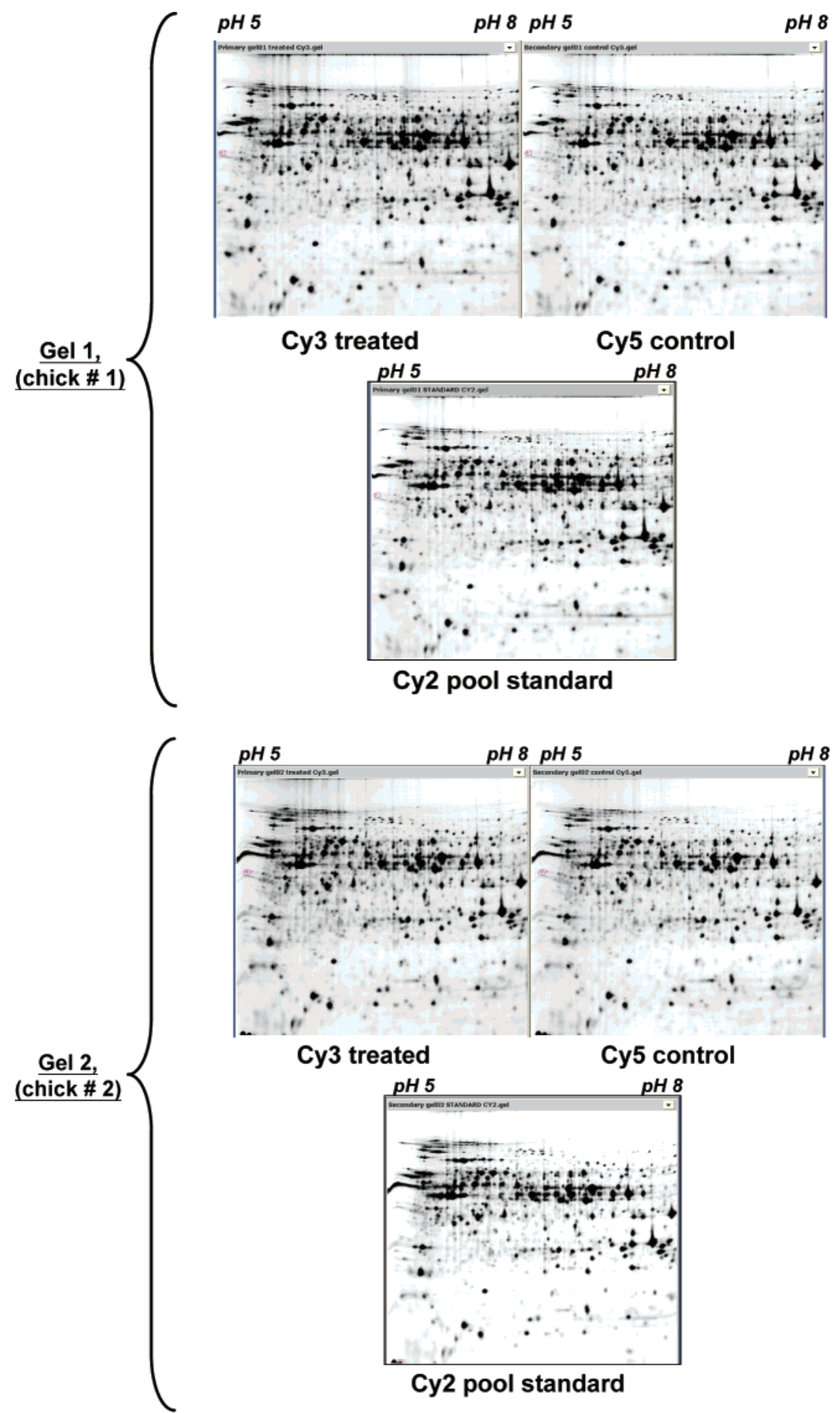

Figure 2. The typical fluorescent protein profiles of the prelabeled retinal tissues by different CyDyes (Cy3 for treated eyes; Cy5 for control eyes; Cy 2 for the pooled standard). The labeled retinal samples of each animal were mixed prior to 2-D PAGE. Each gel contained $50 \mu \mathrm{g}$ of total protein separated by a pH 5-8 IPG strip in the first dimension and $12 \%$ linear polyacrylamide gel in the second dimension electrophoresis. Relevant images were captured by excitation with different lasers using the Typhoon 9400 Variable Mode Imager.

control eyes and the results were shown in Figure $3\left(\log ^{10}\right.$ of all spot volume ratios).

The retinal protein profiles of the two animals were very similar. Figure 3 showed all the protein spots that were present in both the treatment and control eyes. Protein spots were plotted with the log volume ratio on the $x$-axis while the left $y$-axis showed the number of spots and the right $y$-axis showed the spot volume. With the normal distribution curves shown in blue, it could be seen that the normalized volume ratio (curves in red) fitted very well to the data of both animals. After the exclusion of experimental artifacts (e.g., dusts) by the internal software filters, 1505 and 1456 spot pairs were detected in gel 1 and gel 2, respectively. To identify the protein spots that were significantly different in their expressions, the data (5\%) that were two standard deviations (2SD) away from the distribution were recorded (the black vertical lines represents the 2SD). It was found that 47 spots (31\% for gel 1) and 61 spots $(4.2 \%$ for gel 2$)$ showed up-regulation whereas 58 spots 
Gel 1, (chick \#1)

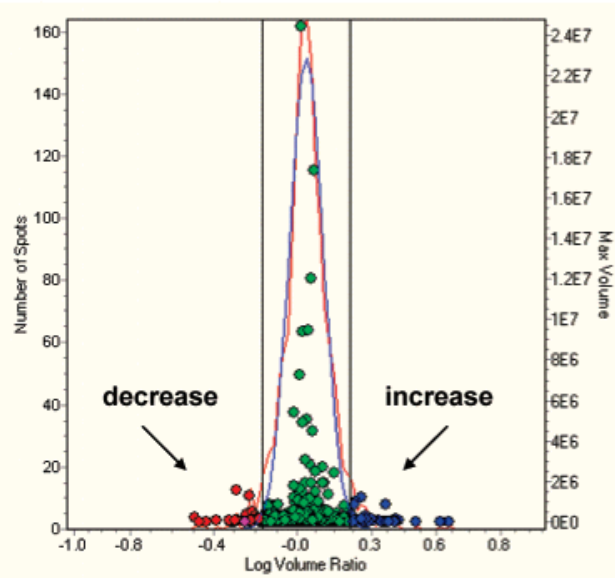

Gel 2, (chick \#2)

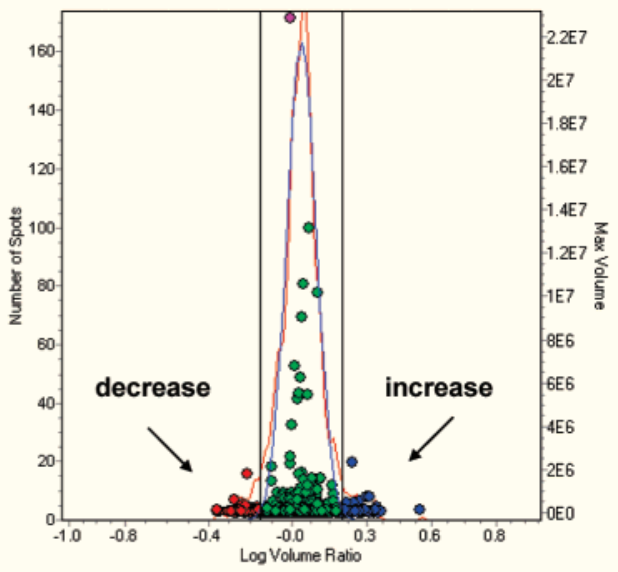

Figure 3. Histograms of the normalized spot volumes within a co-detected image pairs using DIA module for two animals. The diagram showing the total number of spots against log volume ratio simulated a normal distribution (indicated by the red line). By applying the \pm 2 SD filter (the black vertical lines), most of the spots (green spots) fell within the constraint (ratio $=1$, or log [volume ratio] $=0$ ), while the blue spots indicated a volume increase and the red spots indicated a volume decrease in the treatment eyes.

(3.9\% for gel 1) and 55 spots (3.8\% for gel 2) showed downregulation after the 7 -day, $-10 \mathrm{D}$ lens wearing.

Because of the ability of sample multiplexing in one single gel, the spot boundary detection by the DIA of all images was found to be almost identical without further need of gel warping or manual editing which was a difficult but necessary task in the conventional 2-D PAGE. The perfect matching of the protein profiles for fully automated spot matching and quantification ensured confident protein comparison. Moreover, the normalized spot volume data allowed a rapid overview of the differential protein expressions at customized criteria of fold-differences in terms of spot area, spot intensity, or spot volume. However, the DIA analysis is applicable only to different proteins profiles within the same gel.

Image Analysis by DeCyder BVA. Using the BVA module, the differential protein expression of those co-detected pairs between the treatment and control eyes across all four gel runs (two biological replicas and two analytical replicas) could be quantified. A similar approach has been recently described (see ref 32). To identify the "differentially expressed proteins", relatively conservative selection criteria were used in this study. Each of them had to fulfill all of the following criteria: first of all, there was at least 1.5-fold mean difference between the treatment and control protein profile in terms of the spot volume. The use of internal dye standard for DIGE application has been claimed to help detect less than $10 \%$ differences between protein expressions in samples with more than $95 \%$ confidence. ${ }^{33}$ Second, the differentially expressed spot had to be observed in all four gels. Third, it had to achieve a statistically significant fold change $(P \leq 0.05)$ by using the builtin $t$-test statistics software. Finally, these spots were checked manually to confirm that they were true protein spots instead of streaks or other artifacts.

More than 100 of the protein pairs with different expressions were found by the DIA modules in each gel, but only 22 spots met our criteria. Among these differentially expressed proteins, 15 spots showed an up-regulation and only 7 spots showed a down-regulation. Therefore, up-regulation of proteins seemed to be the dominant features in the expression profiles. Their locations on the 2-D gels were annotated and shown in Figure 4.
Effect of CyDyes Reciprocal Stain. Since DIGE Cydyes labeling is a relatively new technique in comparative proteomics, the chemical properties of Cydyes are still being optimized. There was also concern for differential lysine labeling for particular proteins in using different CyDyes. ${ }^{34}$ Actually, it has been reported that there was preferential lysine labeling of particular proteins. ${ }^{28}$ Since this technology has not been applied to retinal sample, we have conducted experiments to study the issue of preferential labeling using a reciprocal labeling method. Furthermore, although the ImageMaster 5 gel analysis software was not originally designed for DIGE application, after converting the 16-bit* .gel DIGE file format to 12 -bit *.tif image format using the Adobe Photoshop imaging software, we have managed to study preferential CyDyes labeling by taking advantage of the built-in image stacking (overlay) function. The differential expressed protein spots between the defocused and control eyes were found to be very similar in the reciprocal stain of gel 1 and gel 3 . Taking the 22 differential expressed spots in Figure 5 as examples, it showed that the up-regulation and down-regulation of protein in response to the $-10 \mathrm{D}$ lens treatment could still be observed in both gels even using different CyDyes labels. Therefore, with the reciprocal stain, we have in effect added an extra internal control to eliminate any possible false positive results caused by the preferential labeling of dyes.

Decyder Analysis after the Second Phase Electrophoresis. To further study the higher molecular weight proteins, the 2-D gels were rerun after the first running was finished and the typhoon imager had captured the first gel image. This continuing and further electrophoretic separation of higher molecular weight proteins was not possible with the conventional electrophoresis after staining. Since the second dimension separation was repeated on all gels in the same system for the same period of time, the multiplexed gels image profiles after the rerun were still very similar. By applying the same filtering criteria, most of the 22 differential expressions could be observed again with significant differences by the Decyder BVA function. The locations of these spots were shown in Figure 6. However, three of the low abundant proteins (no. 979, no. 1257, and no. 1260) were too faint to be detected again in all four 


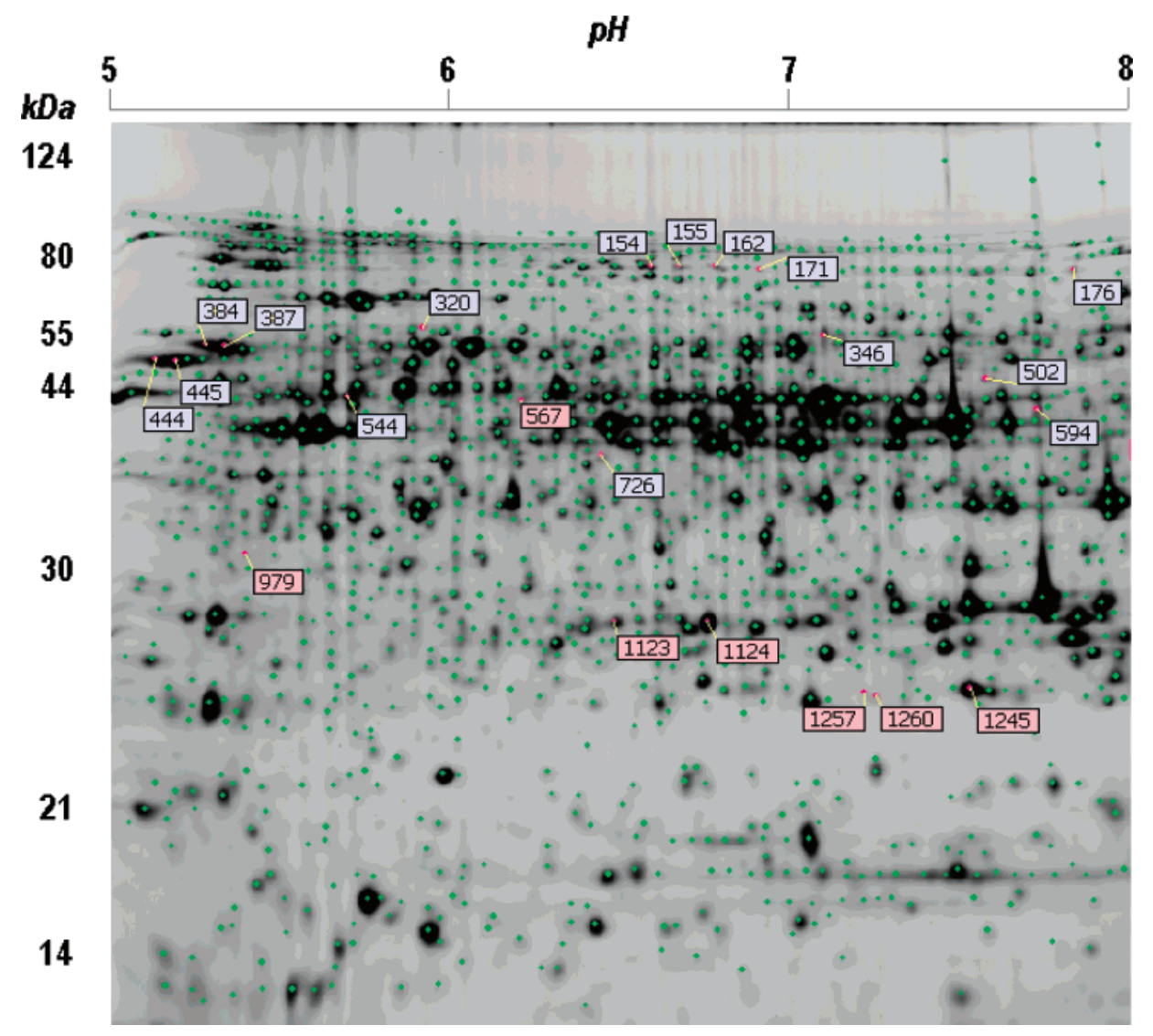

Figure 4. A typical retinal DIGE gel image showing the annotations and locations of differential protein expressions in response to $-10 \mathrm{D}$ lens wearing. The treatment and control samples were labeled with different Cydyes and mixed in 50:50 ratio and separated in $12 \%$ linear gels. Image analysis was performed with the DeCyder BVA module to identify the changes in protein amount. The upregulated proteins were marked in blue color while the down-regulated proteins were marked in red color.

gels owing to the gel rerun. Therefore, they were not included as they no longer fulfilled all of the preset criteria above.

Interestingly, in addition to those previously identified spots, four new spots (one up-regulation and three down-regulations) were found to show significant expression due to better molecular weight in-gel separations after the rerun. Their annotations were also shown and circled in Figure 6. This result showed another advantage of DIGE as compared to the conventional 2-D PAGE in particular for scarce protein samples. Protein profiles can be captured after the designated running time and then the gel, which is assembled in the lowfluorescence glass plate, can be reinstalled for further electrophoresis. The premixed proteins in the same gel were still moving together which can ensure a perfect overlapping of the image profiles for a reliable analysis after rerunning the gel. In addition, as the Typhoon scanner is a point scanner, the photobleaching effects due to constant gel illumination may be avoided. The photobleaching of CyDyes for extended experiment was also found to be insignificant in our study although a slight enhancement of excitation laser power was required in the second phase image capture.

The individual data was also analyzed with the Decyder BVA, and the results of each differentially expressed protein were shown in Figure 7 . The figure showed the actual protein changes of a particular spot in each of the four gels in terms of the spot volume between the treatment and control eyes. In addition, the 3-D simulations of the corresponding spots which represented the typical abundance in term of protein volume in the same gel were also shown. It was particularly useful for comparing high abundant spots (such as spot 1124 and 1245) where the gray-scale intensities were almost saturated in the $2 \mathrm{D}$ view. These 3 -D representations also allowed objective comparisons of the actual spots' intensities and profiles as they were not affected by manual contrast and brightness adjustments. Our results showed that the differential expressions (fold change) in all of the selected spots were very similar and repeatable even across different gels. The spot boundaries as detected by the Decyder software also matched extremely well between the control and treated samples. The $P$ values of paired $t$-test for most of the spots were far less than 0.02 which indicated consistent protein expressions and labeling efficiency in both up-regulated and down-regulated proteins.

The use of a pooled internal standard as in the current DIGE experimental design was not possible in the conventional 2-D PAGE. The Cy2 labeled samples facilitated an accurate spot detection and quantification across different gels. The internal standard was pooled from all protein samples, and by quantifying the ratios (log of the ratios) between the internal standard and experimental samples, one can normalize the spot signals so that comparison across different gels was possible. The intergel comparison allowed an unbiased and accurate statistical calculation. This design is powerful in the studying of time courses or dose-dependent changes of protein signals. The inclusion of an internal pooled standard also helped in differentiating real biological signals from experimental variations. ${ }^{35}$ The benefit of such internal standard was also evident in our data. For example, it could be observed from 
Up-regulation (blue)

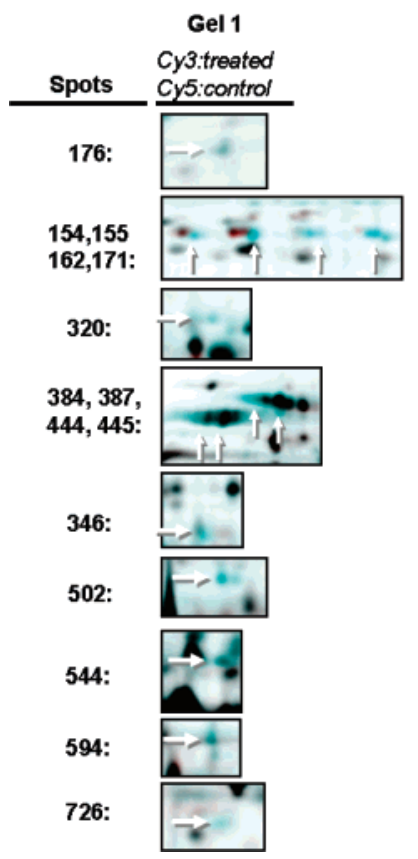

Down-regulation (red)
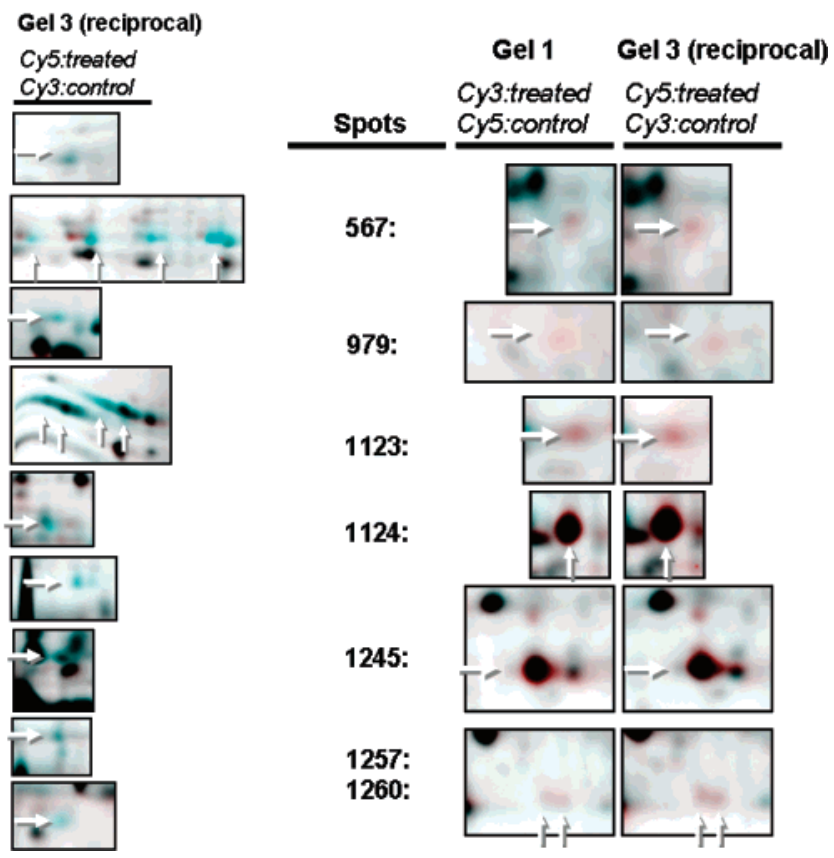

Figure 5. Examples of the $\mathrm{Cy} 3$ and $\mathrm{Cy} 5$ dyes reciprocal labeling effect for the 22 filtered differentially expressed protein spots (indicated by arrows) between gel 1 (treated sample was labeled by Cy3) and gel 3 (treated sample was reciprocally labeled by Cy5). All gel sections were captured by the ImageMaster 5 image analysis software using the gel-stacking function in which up-regulated proteins were simulated as blue color while down-regulated proteins were simulated as red color. Similar protein amounts between the defocused and control eyes were shown in dark color. The differential expressions were found to be consistent when using either CyDyes.

the 3-D views that the protein amounts of spots no. 1123 and no. 1245 seemed to be up-regulated in the treatment eyes if the protein ratios to the internal standard were not taken into consideration. A previous report has addressed this issue and showed that 42 out of $52(80 \%)$, statistical significant real difference, could be overlooked without the internal standard. ${ }^{36}$

Since the internal control has effectively minimized the gel running variations, the DIGE experiment does not need to be repeated as many times as the conventional silver stained 2-D PAGE. In addition, the use of fluorescent labeled CyDyes in DIGE has greatly extended the detection limits and sensitivity of current comparative proteomic studies. ${ }^{34,37}$ DeCyder image analysis software has provided ease in the data analysis and has the capability of fully automated analysis of multiple gels. Compared to other fluorescent dye such as Sypro Ruby, photobleaching is not a major problem with CyDyes. ${ }^{38}$ Because the CyDyes are relatively stable, it is possible to rerun the gel to better profile the high molecular weight proteins.

Protein Identification by MALDI-TOF MS. Using the in-gel digestion and MALD-TOF MS approach, we were able to identify some of the differentially expressed protein spots $(65 \%$ of all the filtered spots). Only weak peptide signals were detected in the rest owing to the limited peptide amount recovered. Almost all identifications were matched to Gallus gallus database except one protein spot (no. 594) which could only have a significant match in the homology databases. These 14 up-regulated and 3 down-regulated identified protein spots were annotated and listed in Table 2. According to the prediction of their subcellular locations using PSORT II (http:// psort.hgc.jp/form2.html), most of them (about 84\%) were assigned to the cytoplasm, whereas the rest were assigned to the nuclear (about 16\%). They corresponded to 10 different proteins plus their isoforms. In addition, their general functions documented in the GeneOntology database (http://www.ebi. ac.uk/ego/) were shown in Table 3. Although their involvements in myopia have yet to be identified, a brief description of the functional roles for each protein was given below.

(No. 154 and No. 162) Dynamin-1. It is one of the three isoforms of dynamin found in synapses and it plays a role in the mitochondrial fusion and fission machinery. The phosphorylation of dynamin-1 is essential for synaptic vesicle endocytosis in nerve terminals, ${ }^{39}$ and it is believed to support axonal outgrowth. Dynamin-1 up-regulation after synapse formation of the chick retinotectal system has been reported. ${ }^{40}$ Recently, Jagasia et al. also showed that DRP-1/dynaminrelated protein was required for inducing mitochondrial fragmentation and programmed cell death during C. elegans development. $^{41}$

(No. 155) Villin 1. Villin 1 is a major structural component of the brush border cytoskeleton, and an actin-associated protein that is bound to the actin core bundle of microvilli. It is also present in the Muller's glial cells (Muller baskets) of the retina. $^{42}$ It belongs to one of the gelsolin superfamily that controls the actin organization by severing filaments, capping filament ends, and nucleating actin assembly. It may also be involved in several cellular processes, including cell motility, control of apoptosis, and regulation of phagocytosis. ${ }^{43}$

(No. 171 and No. 176) Dead (Asp-Glu-Ala-Asp) Box Polypeptide 1. It is a relatively new protein. DEAD box proteins (DDX) are putative RNA unwinding proteins with specific developmental role. Northern and Western blot analyses showed the highest expression of DDX1 was found at early stages of embryonic development in chicken. Tissue maturation is generally accompanied by a decrease in expression, although DDX1 levels remain elevated in the retina and brain during late embryonic stage. In situ hybridization of retinal tissue 


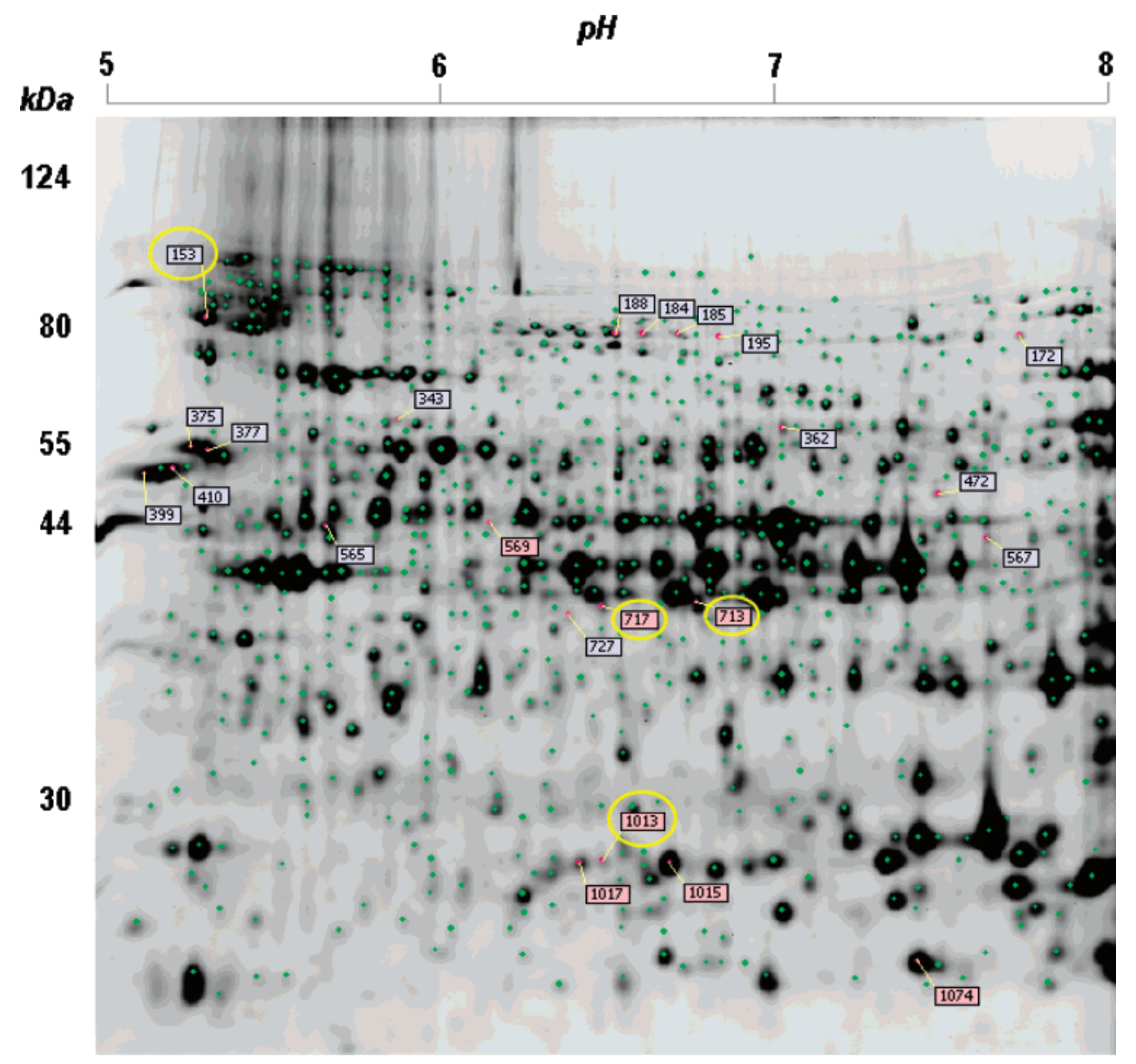

Figure 6. The DIGE gel image after a second phase electrophoresis to resolve the higher molecular weight proteins. Proteins with a molecular weight less than about $25 \mathrm{kDa}$ ran off the gel. Comparing to Figure 4, four additional spots (in circles) were found which have significant differential protein expressions. The up-regulated proteins were marked in blue color, while the down-regulated proteins were marked in red color.

sections revealed a widespread distribution of DDX1 mRNA during early developmental stages with preferential expression in the amacrine and ganglion cells. ${ }^{44}$

(No. 594) Nuclear RNA Helicase (DEAD Family) Homologue-Rat. RNA helicase is a putative enzyme which enables the unwinding of double-stranded RNA. MS PMF results of HLA-B associated transcripts are also members of helicase/ DEAD family which is a large superfamily of proteins conserved from bacteria and viruses to human. ${ }^{45}$ On the sequence level, RNA helicases are identified by the presence of seven to eight conserved motifs which are involved in binding an NTP, generally ATP, and using the energy of hydrolysis to unwind dsRNA. ${ }^{46}$ RNA helicases are therefore thought to act as "RNA chaperones" or "maturases" to ensure that the correct interactions are formed or as energy-dependent "facilitators" that catalyze conformational changes and drive multistep reactions requiring sequential rearrangements of RNA interactions.

(No. 320) Dihydropyrimidinase-Related Protein 2, DRP2 (or Collapsin Response Mediator Protein, CRMP-62). CRMP62 is well-known for its involvement in the neuronal growth cone collapse, and it is localized exclusively in the developing chick nervous system. Introduction of anti-CRMP-62 antibodies into the dorsal root of ganglion neurons can effectively block collapsin-induced growth cone collapse. It was suggested that CRMP-62 may be involved as one of the intracellular components of the related signaling cascade initiated by an unidenti- fied transmembrane collapsin-binding protein. ${ }^{47}$ CRMP was also recently found to play a key role in the neuronal polarization as overexpression of CRMP-2 induced the formation of multiple axons. ${ }^{48}$ CRMP may play a crucial role in regulating axonal growth by interacting with soluble tubulin transport or microtubule assembly. ${ }^{49,50}$ More globally, differences in its protein level between neonatal and adult brain were also recently characterized using the $2 \mathrm{DE}$ approach. ${ }^{51}$

(\#346) Seryl-tRNA Synthetase. The current knowledge related to this protein is relatively limited. The enzyme catalyzes the attachment of an amino acid to its cognate transfer RNA molecule in a highly specific two-step reaction. ${ }^{52}$ Vincent et al. first assembled 2 overlapping clones of SARS, called SERS, from human fetal and infant brain cDNA libraries in $1997 .^{53}$ However, there is still no available information to suggest any functional role of this protein in eye growth.

(No. 384, No. 387, No. 444, No. 445, No. 544) Tubulin. Tubulin is one of the abundant proteins in chick retina according to our previous proteome database results. It is wellknown that the morphological changes are closely related to the reorganization of cytoskeletal proteins such as actin and tubulin. Microtubule ( $\alpha$ - and $\beta$-tubulin) is one of the constituents of many eukaryotic cell structures. They serve a number of cellular functions including cell mobility, intracellular transport, and cell division. Their roles in the ocular system have been proposed in previous studies. During the optic nerve 


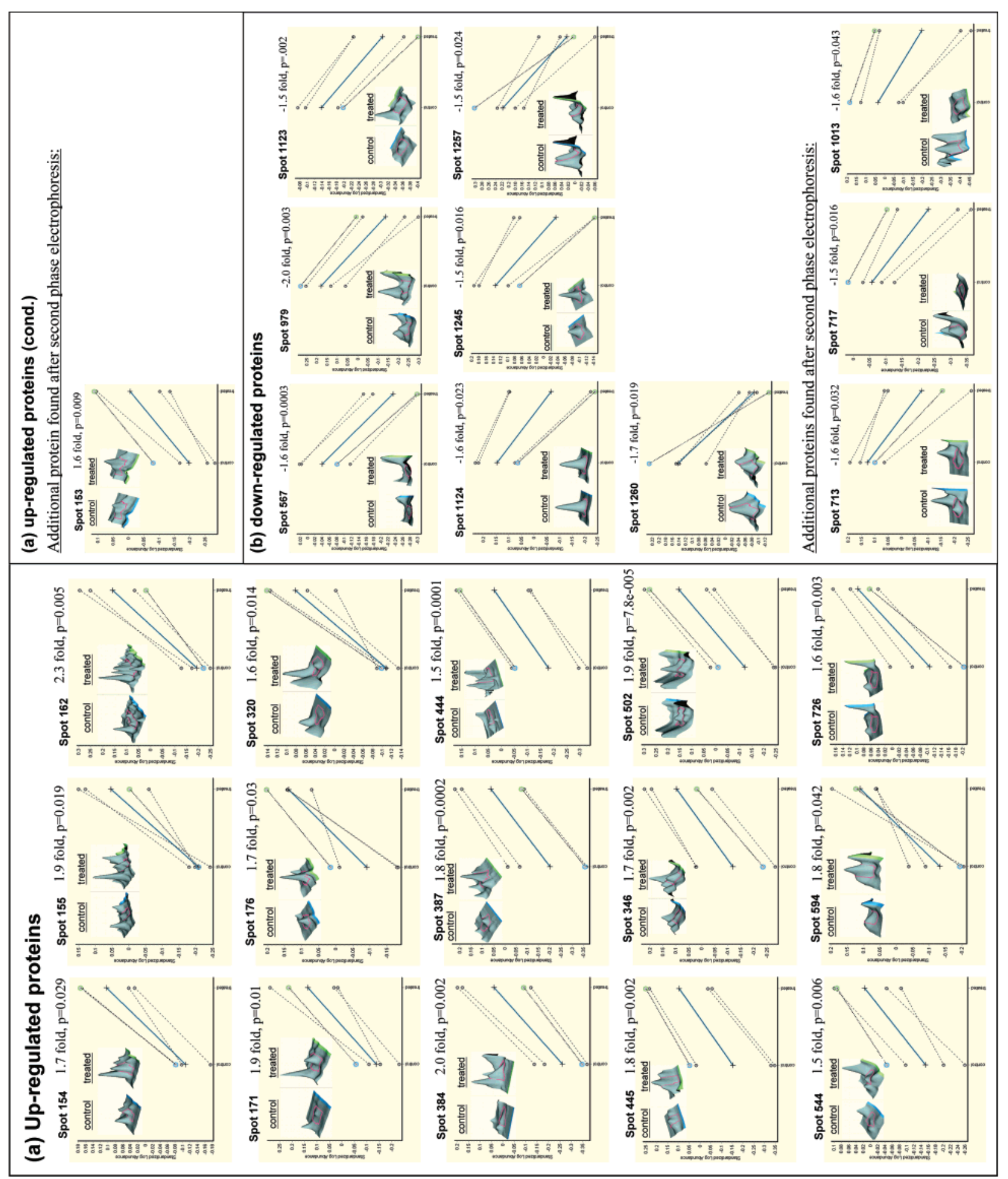

$\frac{0}{3} \frac{1}{\frac{1}{3}}$

ร 
Table 2. Differentially Expressed Chick Retinal Proteins after 7 Days, - 10 D Lens Treatment. The Proteins Were Detected by Decyder Analysis Software Using DIGE Approach and Were Identified by MALDI-TOF MS

\begin{tabular}{|c|c|c|c|c|c|c|c|c|c|c|c|}
\hline $\begin{array}{l}\text { DIGE } \\
\text { spot } \\
\text { no. }\end{array}$ & $\begin{array}{l}\text { NCBI } \\
\text { GI no. }\end{array}$ & mascot protein name & $\begin{array}{l}\text { PIRSF } \\
\text { ID }^{b}\end{array}$ & $\begin{array}{l}\text { MOWSE } \\
\text { score }^{c}\end{array}$ & $\begin{array}{l}\text { rms } \\
\text { error } \\
(\mathrm{ppm})^{d}\end{array}$ & $\begin{array}{l}\text { no. of } \\
\text { matched } \\
\text { peaks / } \\
\text { unmatched } \\
\text { peaks }\end{array}$ & $\begin{array}{l}\text { sequence } \\
\text { coverage }\end{array}$ & $\underset{\mathrm{pI} e^{e}}{\operatorname{mascot}}$ & $\begin{array}{l}\underset{\text { M.W. }}{\operatorname{mascot}} \\
\text { (da) }^{f}\end{array}$ & organism $^{g}$ & $\begin{array}{c}\text { SwissProt/ } \\
\text { TrEMBL } \\
\text { accession } \\
\text { no. }{ }^{h}, \\
\text { SwissProt/ } \\
\text { UniProt } \\
\text { entry } \\
\text { name }^{i}\end{array}$ \\
\hline 154 & 118099274 & $\begin{array}{l}\text { predicted: similar to } \\
\text { dynamin } 1 \text { isoform } 1\end{array}$ & & 197 & 21 & $14 / 5$ & $18.0 \%$ & 6.98 & 97611 & $\begin{array}{l}\text { Gallus } \\
\text { gallus }\end{array}$ & \\
\hline 155 & 45382125 & villin 1 & $\begin{array}{l}\text { PIRSF } \\
002347\end{array}$ & 152 & 25 & $14 / 6$ & $19.7 \%$ & 5.88 & 92821 & $\begin{array}{l}\text { Gallus } \\
\text { gallus }\end{array}$ & $\begin{array}{l}\text { P02640 } \\
\text { VILI_CHICK }\end{array}$ \\
\hline 162 & 118099274 & $\begin{array}{l}\text { predicted: similar to } \\
\text { dynamin } 1 \text { isoform } 1\end{array}$ & & 203 & 20 & $11 / 3$ & $18.0 \%$ & 6.98 & 97611 & $\begin{array}{l}\text { Gallus } \\
\text { gallus }\end{array}$ & \\
\hline 171 & 45383053 & $\begin{array}{l}\text { DEAD (Asp-Glu-Ala-Asp) } \\
\text { box polypeptide } 1\end{array}$ & & 128 & 35 & $11 / 3$ & $18.1 \%$ & 6.64 & 83458 & $\begin{array}{l}\text { Gallus } \\
\text { gallus }\end{array}$ & $\begin{array}{l}\text { Q641Y8, } \\
\text { DDX1_RAT }\end{array}$ \\
\hline 176 & 45383053 & $\begin{array}{l}\text { DEAD (Asp-Glu-Ala-Asp) } \\
\text { box polypeptide } 1\end{array}$ & & 180 & 20 & $14 / 2$ & $23.0 \%$ & 6.64 & 83458 & $\begin{array}{l}\text { Gallus } \\
\text { gallus }\end{array}$ & $\begin{array}{l}\text { Q641Y8, } \\
\text { DDX1_RAT }\end{array}$ \\
\hline \multirow[t]{3}{*}{320} & 3122036 & $\begin{array}{l}\text { dihydropyrimidinase } \\
\text { related protein-2 } \\
\text { (DRP-2) (collapsin } \\
\text { response mediator } \\
\text { protein CRMP-62) }\end{array}$ & $\begin{array}{l}\text { PIRSF } \\
001238\end{array}$ & 152 & 20 & $9 / 5$ & $24.8 \%$ & 5.96 & 62691 & $\begin{array}{l}\text { Gallus } \\
\text { gallus }\end{array}$ & $\begin{array}{l}\text { Q90635, } \\
\text { DPYL2_CHICK }\end{array}$ \\
\hline & 33340025 & $\begin{array}{l}\text { collapsin response } \\
\text { mediator protein-2B }\end{array}$ & $\begin{array}{l}\text { PIRSF } \\
001238\end{array}$ & 152 & 20 & $9 / 5$ & $24.8 \%$ & 6.05 & 62619 & $\begin{array}{l}\text { Gallus } \\
\text { gallus }\end{array}$ & \\
\hline & 45383177 & dihydropyrimidinase-like 2 & & 146 & 20 & $9 / 5$ & $21.0 \%$ & 6.03 & 73908 & $\begin{array}{l}\text { Gallus } \\
\text { gallus }\end{array}$ & \\
\hline 346 & 71897227 & seryl-tRNA synthetase & $\begin{array}{l}\text { PIRSF } \\
001529\end{array}$ & 166 & 9 & $11 / 11$ & $28.8 \%$ & 6.11 & 58837 & $\begin{array}{l}\text { Gallus } \\
\text { gallus }\end{array}$ & \\
\hline \multirow[t]{3}{*}{384} & 71575 & $\begin{array}{l}\text { tubulin } \alpha \text {-chain-chicken } \\
\text { (fragment) }\end{array}$ & & 216 & 19 & $13 / 1$ & $44.8 \%$ & 5.00 & 46256 & $\begin{array}{l}\text { Gallus } \\
\text { gallus }\end{array}$ & $\begin{array}{l}\text { P02552, } \\
\text { TBA1_CHICK }\end{array}$ \\
\hline & 223280 & tubulin $\alpha$ & & 216 & 19 & $13 / 1$ & $44.8 \%$ & 5.00 & 46256 & $\begin{array}{l}\text { Gallus } \\
\text { gallus }\end{array}$ & \\
\hline & 135393 & tubulin $\alpha-1$ chain & $\begin{array}{l}\text { PIRSF } \\
002306\end{array}$ & 216 & 19 & $13 / 1$ & $44.8 \%$ & 5.00 & 46256 & $\begin{array}{l}\text { Gallus } \\
\text { gallus }\end{array}$ & \\
\hline 387 & 71575 & $\begin{array}{l}\text { tubulin } \alpha \text {-chain-chicken } \\
\text { (fragment) }\end{array}$ & & 225 & 9 & $16 / 5$ & $50.0 \%$ & 5.00 & 46256 & $\begin{array}{l}\text { Gallus } \\
\text { gallus }\end{array}$ & $\begin{array}{l}\text { P02552, } \\
\text { TBA1_CHICK }\end{array}$ \\
\hline 444 & 52138699 & tubulin, $\beta 2$ & $\begin{array}{l}\text { PIRSF } \\
002306\end{array}$ & 200 & 20 & $14 / 4$ & $37.1 \%$ & 4.78 & 50377 & $\begin{array}{l}\text { Gallus } \\
\text { gallus }\end{array}$ & $\begin{array}{l}\text { P32882, } \\
\text { TBB2_CHICK }\end{array}$ \\
\hline \multirow[t]{2}{*}{445} & 537407 & $\beta$-tubulin & $\begin{array}{l}\text { PIRSF } \\
002306\end{array}$ & 343 & 25 & $23 / 3$ & $54.0 \%$ & 4.79 & 50172 & $\begin{array}{l}\text { Cricetulus } \\
\text { griseus }\end{array}$ & $\begin{array}{l}\text { P09203, } \\
\text { TBB1_CHICK } \\
\text { P32882, } \\
\text { TBB2_CHICK }\end{array}$ \\
\hline & 118099195 & $\begin{array}{l}\text { predicted: hypothetical protein } \\
(\beta \text {-tubulin) }\end{array}$ & & 343 & 25 & $23 / 3$ & $54.0 \%$ & 4.78 & 50285 & $\begin{array}{l}\text { Gallus } \\
\text { gallus }\end{array}$ & $\begin{array}{l}\text { P09206, } \\
\text { TBB3_CHICK }\end{array}$ \\
\hline 502 & 71895629 & septin 6 & $\begin{array}{l}\text { PIRSF } \\
006698\end{array}$ & 181 & 38 & $13 / 6$ & $35.9 \%$ & 6.67 & 48999 & $\begin{array}{l}\text { Gallus } \\
\text { gallus }\end{array}$ & $\begin{array}{l}\text { Q14141, } \\
\text { SEPT6_HUMAN }\end{array}$ \\
\hline \multirow[t]{2}{*}{544} & 32967422 & $\beta$-tubulin & & 234 & 22 & $17 / 8$ & $49.0 \%$ & 5.95 & 43514 & $\begin{array}{l}\text { Sycon sp. } \\
A R-2003\end{array}$ & $\begin{array}{l}\text { P09206, } \\
\text { TBB3_CHICK }\end{array}$ \\
\hline & 118099195 & $\begin{array}{l}\text { predicted: hypothetical protein } \\
\text { (beta tubulin) }\end{array}$ & & 214 & 22 & $16 / 9$ & $40.0 \%$ & 4.78 & 50285 & $\begin{array}{l}\text { Gallus } \\
\text { gallus }\end{array}$ & \\
\hline \multirow[t]{5}{*}{594} & 539961 & $\begin{array}{l}\text { nuclear RNA helicase } \\
\text { (DEAD family) } \\
\text { homologue-rat }\end{array}$ & & 123 & 48 & $7 / 3$ & $21.0 \%$ & 6.65 & 46100 & $\begin{array}{l}\text { Rattus } \\
\text { norvegicus }\end{array}$ & $\begin{array}{l}\text { Q5ZHZD, } \\
\text { UAP56_CHICK }\end{array}$ \\
\hline & 114606329 & $\begin{array}{l}\text { predicted: HLA-B associated } \\
\text { transcript } 1 \text { isoform } 9\end{array}$ & & 123 & 48 & $7 / 3$ & $19.0 \%$ & 5.36 & 49223 & $\begin{array}{l}\text { Pan } \\
\text { troglodytes }\end{array}$ & \\
\hline & 114606331 & $\begin{array}{l}\text { predicted: HLA-B associated } \\
\text { transcript } 1 \text { isoform } 1\end{array}$ & & 123 & 48 & $7 / 3$ & $19.0 \%$ & 5.50 & 49490 & $\begin{array}{l}\text { Pan } \\
\text { troglodytes }\end{array}$ & \\
\hline & 114606315 & $\begin{array}{l}\text { predicted: HLA-B associated } \\
\text { transcript } 1 \text { isoform } 7\end{array}$ & & 123 & 48 & $7 / 3$ & $19.0 \%$ & 5.58 & 49738 & $\begin{array}{l}\text { Pan } \\
\text { troglodytes }\end{array}$ & \\
\hline & 62897383 & $\begin{array}{l}\text { HLA-B associated } \\
\text { transcript } 1 \text { variant }\end{array}$ & $\begin{array}{l}\text { PIRSF } \\
003023\end{array}$ & 123 & 48 & $7 / 3$ & $19.0 \%$ & 5.51 & 49444 & $\begin{array}{l}\text { Homo } \\
\text { sapiens }\end{array}$ & \\
\hline 1123 & 71895985 & $\begin{array}{l}\text { phosphoglycerate } \\
\text { mutase } 1 \text { (brain) }\end{array}$ & $\begin{array}{l}\text { PIRSF } \\
001490\end{array}$ & 134 & 32 & $7 / 0$ & $45.3 \%$ & 7.03 & 29051 & $\begin{array}{l}\text { Gallus } \\
\text { gallus }\end{array}$ & $\begin{array}{l}\text { Q5ZLN1, } \\
\text { PGAM1_CHICK }\end{array}$ \\
\hline 1124 & 71895985 & $\begin{array}{l}\text { phosphoglycerate } \\
\text { mutase } 1 \text { (brain) }\end{array}$ & $\begin{array}{l}\text { PIRS } \\
\text { F001490 }\end{array}$ & 191 & 42 & $9 / 2$ & $52.0 \%$ & 7.03 & 29051 & $\begin{array}{l}\text { Gallus } \\
\text { gallus }\end{array}$ & $\begin{array}{l}\text { Q5ZLN2, } \\
\text { PGAM1_CHICK }\end{array}$ \\
\hline \multirow[t]{2}{*}{1245} & 50751518 & $\begin{array}{l}\text { predicted: similar to } \\
\text { natural killer cell } \\
\text { enhancing factor } \\
\text { isoform } 4\end{array}$ & & 144 & 34 & $9 / 4$ & $34.0 \%$ & 8.24 & 22529 & $\begin{array}{l}\text { Gallus } \\
\text { gallus }\end{array}$ & \\
\hline & 118094468 & $\begin{array}{l}\text { predicted: similar to } \\
\text { natural killer cell } \\
\text { enhancing factor } \\
\text { isoform } 4\end{array}$ & & 144 & 34 & $9 / 4$ & $33.0 \%$ & 8.24 & 23333 & $\begin{array}{l}\text { Gallus } \\
\text { gallus }\end{array}$ & \\
\hline
\end{tabular}

${ }^{a}$ A GI number (GenInfo Identifier) is assigned to each nucleotide and protein sequence accessible through the The National Center for Biotechnology Information search systems (NCBI). ${ }^{b}$ The PIR (Protein Information Resource) is a nonredundant reference protein database at Georgetown University Medical Center. ${ }^{\mathrm{c}}$ Score for the protein with significant match calculated by Mowse scoring algorithm in the Mascot system. ${ }^{d}$ The mass differences (error) between the calculated and experimental mass values for the matched protein in ppm. ${ }^{e}$ tTheoretical values of the isoelectric point and molecular weight obtained in the database search using Mascot system. ${ }^{g}$ The species identified with significant score for a particular protein. ${ }^{h}$ SwissProt is a protein knowledgebase maintained collaboratively by the Swiss Institute of Bioinformatics and the The European Bioinformatics Institute; TrEMBL is a computer-annotated supplement of SwissProt that contains all the translations of EMBL nucleotide sequence entries not yet integrated in Swiss-Prot. ${ }^{i}$ The UniProt (Universal Protein Resource) is a comprehensive catalogue of protein informati01097on created by the consortium members PIR, European Bioinformatics Institute and Swiss Institute of Bioinformatics.

regeneration process in bullfrog, there was a rapid and transient increase in the messenger RNA of $\alpha$-tubulin gene. ${ }^{54}$ Also, using
Northern blot analysis and in situ hybridization, it was found that the rat homologue of $\alpha$-tubulin was highly expressed 
Table 3. The Expression Changes and Documented Functions According to the GeneOntology of Identified Retinal Proteins in Table 2

\begin{tabular}{|c|c|c|c|c|}
\hline spot no. & protein name & expression & molecular function(s) & biological process(es) \\
\hline no. 154 , no. 162 & Dynamin-1 & up-regulation & $\begin{array}{l}\text { protein binding; } \\
\text { GTPase activity }\end{array}$ & $\begin{array}{l}\text { endocytosis; multicellular } \\
\text { organismal development }\end{array}$ \\
\hline no. 155 & Villin 1 & up-regulation & - & - \\
\hline no. 171 , no. 176 & $\begin{array}{l}\text { Dead (Asp-Glu-Ala-Asp) } \\
\text { box polypeptide }\end{array}$ & up-regulation & $\begin{array}{l}\text { ATP binding; } \\
\text { helicase activity; } \\
\text { RNA binding; } \\
\text { nucleic acid binding; } \\
\text { hydrolase activity }\end{array}$ & $\begin{array}{l}\text { multicellular organismal } \\
\text { development }\end{array}$ \\
\hline \multirow[t]{2}{*}{ no. 594} & $\begin{array}{l}\text { nuclear RNA helicase } \\
\text { (DEAD family) } \\
\text { homologue-rat }\end{array}$ & up-regulation & nucleotide binding; & mRNA processing; \\
\hline & & & $\begin{array}{l}\text { RNA binding; } \\
\text { helicase activity; } \\
\text { ATP binding; } \\
\text { hydrolase activity }\end{array}$ & RNA splicing \\
\hline no. 320 & CRMP-62 & up-regulation & hydrolase activity & $\begin{array}{l}\text { multicellular organismal } \\
\text { development; } \\
\text { nervous system } \\
\text { development; } \\
\text { cell differentiation }\end{array}$ \\
\hline no. 346 & Seryl-tRNA synthetase & up-regulation & - & - \\
\hline \multirow[t]{2}{*}{$\begin{array}{l}\text { no. } 384 \text {, no. } 387 \text {, no. } 444 \text {, } \\
\text { no. } 445 \text {, no. } 544\end{array}$} & Tubulin & up-regulation & GTPase activity; & microtubule-based process; \\
\hline & & & structural molecule activity; & $\begin{array}{l}\text { microtubule-based } \\
\text { movement; }\end{array}$ \\
\hline no. 502 & Septin 6 & up-regulation & $\begin{array}{l}\text { GTP binding } \\
\text { protein binding; } \\
\text { nucleotide binding; } \\
\text { GTP binding }\end{array}$ & $\begin{array}{l}\text { protein polymerization } \\
\text { cytokinesis; } \\
\text { cell cycle; } \\
\text { cell division }\end{array}$ \\
\hline \multirow[t]{2}{*}{ no. 1123 and no. 1124} & $\begin{array}{l}\text { phosphoglycerate mutase } \\
1 \text { (brain) }\end{array}$ & down-regulation & catalytic activity; & glycolysis; \\
\hline & & & $\begin{array}{l}\text { intramolecular } \\
\text { transferase activity, } \\
\text { phosphotransferases } \\
\text { hydrolase activity; } \\
\text { isomerase activity }\end{array}$ & metabolic process \\
\hline no. 1245 & $\begin{array}{l}\text { predicted: similar to natural } \\
\text { killer cell enhancing } \\
\text { factor isoform }\end{array}$ & down-regulation & - & - \\
\hline
\end{tabular}

during the extension of neuronal processes. ${ }^{55}$ In addition, $\beta$-tubulin was also found to express in the differentiating retinal neuroblasts, and it may be important in the retinal ganglion cell differentiation. ${ }^{56}$ A time course of the expression of $\beta$-tubulin during development has been characterized in the mouse retina. ${ }^{57}$

(No. 502) Septin 6. Septins are GTPases for cytokinesis and other processes requiring spatial organization of the cell cortex, but their exact molecular functions in these processes are unknown. ${ }^{58}$ Septin 6 was found to be abundantly expressed in the adult mouse brain according to an immunohistochemical study. It was found to be associated with synaptic vesicles in various brain regions. ${ }^{59}$ Meanwhile, growing evidence has suggested that mammalian septins functionally or physically interact with a number of molecules such as actin, actinbinding proteins, and proteins of membrane fusion machinery. ${ }^{60}$ Mammalian septins were recently shown to regulate microtubule stability through interaction with the microtubulebinding protein MAP4. ${ }^{61}$

(No. 1123 and No. 1124) Phosphoglycerate Mutase 1 (Brain). This protein was also known as phosphoglycerate mutase 1 (PGAM1_CHICK) in SwissProt protein database. It is a glycolytic enzyme that catalyzes the interconversion of 3- and 2-phosphoglycerate with 2,3-bisphosphoglycerate as the primer of the reaction. The protein shares the same family with our previous identified protein of phosphoglycerate mutase type B subunit, PGM-B in retinal developmental growth. ${ }^{27}$ Previous study also showed its up-regulation in the development of trisomy 19 mice. ${ }^{62}$ A more recent developmental study in chick embryo also showed similar up-regulation in the protein expression. ${ }^{63}$ DiMauro et al. even suggested that both PGAM-A and PGAM-B are the same protein. ${ }^{64}$ Furthermore, our PMF identification for no. 1124 also confirmed the significant sequence similarity of these spots to PGAM-B.

(No. 1245) Predicted: Similar to Natural Killer Cell Enhancing Factor Isoform. This protein belongs to the peroxiredoxin (Prdx) family. Peroxiredoxins are recently reviewed as multifunctional antioxidant thioredoxin-dependent peroxidises. The major functions of Prdxs include cellular protection against oxidative stress, modulation of intracellular signaling cascades, and regulation of cell proliferation. ${ }^{65,66} \operatorname{Prdx} I$ is the most abundant and ubiquitously distributed in mammalian tissues. According to the study by Neumann et al., Prdx1-deficient fibroblasts showed decreased proliferation and increased sensitivity to oxidative DNA damage, whereas mice lacking Prdx1 showed abnormalities in numbers, phenotype, and function of natural killer cells. They suggested that Prdxl was an important defense against oxidants in aging mice. ${ }^{67}$ Other peroxiredoxin family members, peroxiredoxin 3 (also known as antioxidant protein 1) and peroxiredoxin 5, were shown to reduce apoptosis and were thought to be responsible for the regulation of cellular proliferation, differentiation, and antioxidative function in different parts of the body. ${ }^{68-70}$ Furthermore, a recent study showed that peroxiredoxin 2 deficiency increased the production of peroxide, enhanced activation of PDGF receptor, and subsequently increased cell proliferation and migration in response to PDGF. ${ }^{71}$ 


\section{Discussion}

By and large, the compensated myopic growth in terms of differential protein expression was very similar between different animals. Nevertheless, given that the interanimal variations in protein expression is known to be higher, the differential protein profiles between the defocus and control eyes of the same animal were compared so as to further minimize variation. Moreover, binocular visual system provides a unique platform for comparative proteomics study as different manipulations of the two eyes of a single animal, with same genetic makeup, were possible.

Proteins that are differentially expressed in diseased conditions may be of interest as potential diagnostic markers and for future clinical applications. Most of the identified proteins in the present study have previously been found in the nervous system and have been described in the literatures. However, their roles in myopia development are yet to be established. Considering that the lens-induced myopia involves mainly axial elongation, it was not surprising to see up-regulations of the cytosketetal proteins (Tubulin, no. 384, no. 387, no. 444, no. 445 , no. 544), actin-associated protein (Villin 1, no. 155), or those responsible for the retinal axon growth (Dynamin-1, no. 154 and no. 162) in the treatment eyes. Protein with multiple functions may simultaneously involve in axonal growth, actin organization, or neuronal cone growth and signaling (CRMP$62, \# 320$ ). They may be therefore actively participating in the compensated ocular growth. Interestingly, a recent similar study employing traditional 2DE also suggested CRMP-62 protein as a "go signal" to promote the myopic growth in chicks. ${ }^{27}$ In addition, two proteins (PGAM1, no. 1123 and no. 1124) that could be linked closely to normal ocular development were also identified in our previous study. ${ }^{72}$ However, whether the down-regulation of PGAM is a passive response to the growing process remains unknown. On the other hand, other upstream modification is also likely to take place in the RNA level (DEAD family, no. 171 and no. 176, no. 594; SeryltRNA synthetase, no. 346). Furthermore, since proteins such as phosphoglycerate mutase 1 (no. 1123 and no. 1124), dihydropyrimidinase related protein-2 (DRP-2) (no. 320) and natural killer cell enhancing factor (peroxiredoxin) (no. 1245) are all involved in the oxidation processes at different levels, it is thus conceivable that the increase in oxidative stress is concurrent with myopia development and may contribute to the pathology in extreme high myopia. Our findings, using proteomic approach and in the light of current literatures of protein functions, may provide a global understanding of the complex protein expressions and interplay during the compensated myopic growth. However, it should be noted that we have set criteria on defining differentially expressed proteins stringently and conservatively so that only proteins with the most significant differences were studied. In addition, we anticipated that more candidate proteins could be discovered by using IPGs of different $\mathrm{pH}$ ranges or zoom-gels. Therefore, our results did not necessarily give the full picture on all protein changes and the regulatory mechanisms at the protein level in myopia are likely to be much more complicated.

On technical aspects, it has previously been shown that the CyDye binding was compatible to protein identification with mass spectrometry techniques using the minimal labeling approach (to less than 5\%)..$^{28,73,74}$ In the present study, protein identifications were performed on preparative 2-D gels by using the conventional PAGE since we found that the MS compatible silver stain on the original gels was not satisfactory after the
DIGE electrophoresis was rerun. Usually, the highest pixel area excised represented the highest abundance of a particular protein spot on gel with the MS compatible stain approach. However, in the case of DIGE, the spot intensity may only represent the location of the lysine but not the protein itself. This discrepancy poses difficulty in accurately locating the proteins according to its stain during excision of protein spots. Therefore, it may hinder the success of recovering sufficient peptides during in-gel protein digestion for later MS analysis. A clear benefit of using separate preparative gels over the CyDye labeled gel for protein identification is that more proteins can be recovered from the preparative gel for later successful MS analysis.

Although there are apparent merits in the DIGE technique, it is not without limitations. The DIGE approach is not applicable to study proteins which have no lysine group because of the lysine labeling property of the CyeDyes. Also, the DIGE technique still shares some of the inherent limitations of the conventional 2-D PAGE technique. For example, it is ineffective in detecting membrane-bound proteins, proteins of extreme $\mathrm{pH}$, and low abundance proteins. The DIGE system is technically inconvenient in searching for the on-off protein differences (instead of up- or down-regulation) between the treatment and control groups because of the absence of the counterpart proteins in either of the samples. In theory, the latter two problems could be remedied by capturing multiple profiles with increasing laser power to extend the dynamic detection range which is not possible in the conventional silverstaining technique. A new DIGE development has recently been reported which uses the "saturation labeling" method to label the cysteine residues. This new approach may further extend the application of DIGE and overcome some of the current limitations of DIGE. ${ }^{28}$

\section{Concluding Remarks}

To tackle complex biological events such as myopia with proteomics, the quest for accuracy is as important and powerful as aiming for high throughput. This study demonstrated for the first time that the DIGE approach can effectively identify retinal protein candidates which were differentially expressed in the compensated myopic eye. Considering the protein identification results, it is plausible that signaling induced cytoskeleton remodelling involving axonal outgrowth, neuronal growth, and actin/tubulin reorganization at the retinal level are expected during the myopic eye growth. Also, specific proteins with a previously known function of developmental role were also found in this study. Although the full picture of protein interactions in the induced emmetropization remains unclear, this study has provided new candidate proteins and their pathways to further our understanding of the mechanism of myopia. Elucidation of their exact roles in the emmetropization process may hold the vital keys for future treatment and management of human myopia.

Acknowledgment. This work was supported partly by a grant from "The HKPU Area of Strategic DevelopmentCentre for Myopia Research (A360)" funding and partly by Grant G-YD29 from the Research Committee, The Hong Kong Polytechnic University. Mr. Thomas C. Lam was supported by a Postgraduate Studentship (Account No. G-W080).

Supporting Information Available: NCBInr PMF search results for identified chick retinal proteins. This material is available free of charge via the Internet at http://pubs.acs.org. 


\section{References}

(1) Eder, M.; Schlattner, U.; Becker, A.; Wallimann, T.; Kabsch, W.; Fritz-Wolf, K. Crystal structure of brain-type creatine kinase at 1.41 A resolution. Protein Sci. 1999, 8 (11), 2258-69.

(2) Akiba, J. Prevalence of posterior vitreous detachment in high myopia. Ophthalmology 1993, 100 (9), 1384-8.

(3) Jonas, J. B.; Budde, W. M. Optic nerve damage in highly myopic eyes with chronic open-angle glaucoma. Eur. J. Ophthalmol. 2005, 15 (1), 41-7.

(4) Burton, T. C. The influence of refractive error and lattice degeneration on the incidence of retinal detachment. Trans. Am. Ophthalmol. Soc. 1989, 87, 143-55; discussion 155-7.

(5) Banker, A. S.; Freeman, W. R. Retinal detachment. Ophthalmol. Clin. North Am. 2001, 14 (4), 695-704.

(6) Avila, M. P.; Weiter, J. J.; Jalkh, A. E.; Trempe, C. L.; Pruett, R. C.; Schepens, C. L. Natural history of choroidal neovascularization in degenerative myopia. Ophthalmology 1984, 91 (12), 1573-81.

(7) Cedrone, C.; Nucci, C.; Scuderi, G.; Ricci, F.; Cerulli, A.; Culasso, F. Prevalence of blindness and low vision in an Italian population: a comparison with other European studies. Eye 2006, 20 (6), 661-7.

(8) Rose, K.; Smith, W.; Morgan, I.; Mitchell, P. The increasing prevalence of myopia: implications for Australia. Clin. Exp. Ophthalmol. 2001, 29 (3), 116-20.

(9) Logan, N. S.; Davies, L. N.; Mallen, E. A.; Gilmartin, B. Ametropia, and ocular biometry in a U.K. university student population. Optom. Visual Sci. 2005, 82 (4), 261-6.

(10) Villarreal, M. G.; Ohlsson, J.; Abrahamsson, M.; Sjostrom, A.; Sjostrand, J. Myopisation: the refractive tendency in teenagers. Prevalence of myopia among young teenagers in Sweden. Acta Ophthalmol. Scand. 2000, 78 (2), 177-81.

(11) Berdeaux, G.; Alio, J. L.; Martinez, J. M.; Magaz, S.; Badia, X. Socioeconomic aspects of laser in situ keratomileusis, eyeglasses, and contact lenses in mild to moderate myopia. J. Cataract Refract. Surg. 2002, 28 (11), 1914-23.

(12) Lam, C. S.; Goldschmidt, E.; Edwards, M. H. Prevalence of myopia in local and international schools in Hong Kong. Optom. Visual Sci. 2004, 81 (5), 317-22.

(13) Edwards, M. The refractive status of Hong Kong Chinese infants Ophthalmol. Physiol. Opt. 1991, 11 (4), 297-303.

(14) Unlu, M.; Morgan, M. E.; Minden, J. S. Difference gel electrophoresis: a single gel method for detecting changes in protein extracts. Electrophoresis 1997, 18 (11), 2071-7.

(15) Wiesel, T. N.; Raviola, E. Myopia and eye enlargement after neonatal lid fusion in monkeys. Nature 1977, 266 (5597), 66-8.

(16) Wallman, J.; Turkel, J.; Trachtman, J. Extreme myopia produced by modest change in early visual experience. Science 1978, 201 (4362), 1249-51.

(17) Wildsoet, C.; Wallman, J. Choroidal and scleral mechanisms of compensation for spectacle lenses in chicks. Vision Res. 1995, 35 (9), 1175-94.

(18) Schmid, K. L.; Wildsoet, C. F. Effects on the compensatory responses to positive and negative lenses of intermittent lens wear and ciliary nerve section in chicks. Vision Res. 1996, 36 (7), 102336.

(19) Wallman, J.; Adams, J. I.; Trachtman, J. N. The eyes of young chickens grow toward emmetropia. Invest. Ophthalmol. Visual Sci. 1981, 20 (4), 557-61.

(20) Butterfield, D. A.; Boyd-Kimball, D. Proteomics analysis in Alzheimer's disease: new insights into mechanisms of neurodegeneration. Int. Rev. Neurobiol. 2004, 61 159-88.

(21) Dixon, D. W.; Gill, A. F.; Giribabu, L.; Vzorov, A. N.; Alam, A. B. Compans, R. W. Sulfonated naphthyl porphyrins as agents against HIV-1. J. Inorg. Biochem. 2005, 99 (3), 813-21.

(22) Sparre, T.; Bergholdt, R.; Nerup, J.; Pociot, F. Application of genomics and proteomics in Type 1 diabetes pathogenesis research. Expert Rev. Mol. Diagn. 2003, 3 (6), 743-57.

(23) Garcia-Foncillas, J.; Bandres, E.; Zarate, R.; Remirez, N. Proteomic analysis in cancer research: potential application in clinical use. Clin. Transl. Oncol. 2006, 8 (4), 250-61.

(24) Ren, Y.; He, Q. Y.; Fan, J.; Jones, B.; Zhou, Y.; Xie, Y.; Cheung, C Y.; Wu, A.; Chiu, J. F.; Peiris, J. S.; Tam, P. K. The use of proteomics in the discovery of serum biomarkers from patients with severe acute respiratory syndrome. Proteomics 2004, 4 (11), 3477-84.

(25) Matsumoto, H.; O'Tousa, J. E.; Pak, W. L. Light-induced modification of Drosophila retinal polypeptides in vivo. Science 1982, 217 (4562), 839-41.

(26) Semple-Rowland, S. L.; Ulshafer, R. J. Analysis of proteins in developing rd (retinal degeneration) chick retina using twodimensional gel electrophoresis. Exp. Eye Res. 1989, 49 (4), 66575 .
(27) Bertrand, E.; Fritsch, C.; Diether, S.; Lambrou, G.; Mueller, D.; Schaeffel, F.; Schindler, P.; Schmid, K. L.; van Oostrum, J.; Voshol, H. Identification of Apolipoprotein A1 as a "STOP" signal for myopia. Mol. Cell. Proteomics 2006.

(28) Tonge, R.; Shaw, J.; Middleton, B.; Rowlinson, R.; Rayner, S.; Young, J.; Pognan, F.; Hawkins, E.; Currie, I.; Davison, M. Validation and development of fluorescence two-dimensional differential gel electrophoresis proteomics technology. Proteomics 2001, 1 (3), 377-96.

(29) Schuerenberg, M.; Luebbert, C.; Eickhoff, H.; Kalkum, M.; Lehrach, H.; Nordhoff, E. Prestructured MALDI-MS sample supports. Anal. Chem. 2000, 72 (15), 3436-42.

(30) Johnson, T.; Bergquist, J.; Ekman, R.; Nordhoff, E.; Schurenberg, M.; Kloppel, K. D.; Muller, M.; Lehrach, H.; Gobom, J. A CEMALDI interface based on the use of prestructured sample supports. Anal. Chem. 2001, 73 (8), 1670-5.

(31) Irving, E. L.; Sivak, J. G.; Curry, T. A.; Callender, M. G. Chick eye optics: zero to fourteen days. J. Comp. Physiol., A 1996, 179 (2), 185-94.

(32) Berendt, F. J.; Frohlich, T.; Schmidt, S. E.; Reichenbach, H. D.; Wolf, E.; Arnold, G. J. Holistic differential analysis of embryoinduced alterations in the proteome of bovine endometrium in the preattachment period. Proteomics 2005, 5 (10), 2551-60.

(33) Marouga, R.; David, S.; Hawkins, E. The development of the DIGE system: 2D fluorescence difference gel analysis technology. Anal. Bioanal. Chem. 2005, 382 (3), 669-78.

(34) He, Q. Y.; Chiu, J. F. Proteomics in biomarker discovery and drug development. J. Cell. Biochem. 2003, 89 (5), 868-86.

(35) Alban, A.; David, S. O.; Bjorkesten, L.; Andersson, C.; Sloge, E.; Lewis, S.; Currie, I. A novel experimental design for comparative two-dimensional gel analysis: Two-dimensional difference gel electrophoresis incorporating a pooled internal standard. Proteomics 2003, 3 (1), 36-44.

(36) Friedman, D. B.; Hill, S.; Keller, J. W.; Merchant, N. B.; Levy, S E.; Coffey, R. J.; Caprioli, R. M. Proteome analysis of human colon cancer by two-dimensional difference gel electrophoresis and mass spectrometry. Proteomics 2004, 4 (3), 793-811.

(37) Kolkman, A.; Dirksen, E. H.; Slijper, M.; Heck, A. J. Double standards in quantitative proteomics: direct comparative assessment of difference in gel electrophoresis and metabolic stable isotope labeling. Mol. Cell. Proteomics 2005, 4 (3), 255-66.

(38) Gharbi, S.; Gaffney, P.; Yang, A.; Zvelebil, M. J.; Cramer, R.; Waterfield, M. D.; Timms, J. F. Evaluation of two-dimensional differential gel electrophoresis for proteomic expression analysis of a model breast cancer cell system. Mol. Cell. Proteomics 2002, 1 (2), 91-8.

(39) Smillie, K. J.; Cousin, M. A. Dynamin I phosphorylation and the control of synaptic vesicle endocytosis. Biochem. Soc. Symp. 2005 (72), 87-97.

(40) Bergmann, M.; Grabs, D.; Rager, G. Developmental expression of dynamin in the chick retinotectal system. J. Histochem. Cytochem. 1999, 47 (10), 1297-306.

(41) Jagasia, R.; Grote, P.; Westermann, B.; Conradt, B. DRP-1mediated mitochondrial fragmentation during EGL-1-induced cell death in C. elegans. Nature 2005, 433 (7027), 754-60.

(42) Nordhoff, E.; Egelhofer, V.; Giavalisco, P.; Eickhoff, H.; Horn, M.; Przewieslik, T.; Theiss, D.; Schneider, U.; Lehrach, H.; Gobom, J. Large-gel two-dimensional electrophoresis-matrix assisted laser desorption/ionization-time of flight-mass spectrometry: an analytical challenge for studying complex protein mixtures. Electrophoresis 2001, 22 (14), 2844-55.

(43) Silacci, P.; Mazzolai, L.; Gauci, C.; Stergiopulos, N.; Yin, H. L.; Hayoz, D. Gelsolin superfamily proteins: key regulators of cellular functions. Cell. Mol. Life Sci. 2004, 61 (19-20), 2614-23.

(44) Godbout, R.; Packer, M.; Katyal, S.; Bleoo, S. Cloning and expression analysis of the chicken DEAD box gene DDX1. Biochim. Biophys. Acta 2002, 1574 (1), 63-71.

(45) Tanner, N. K.; Linder, P. DExD/H box RNA helicases: from generic motors to specific dissociation functions. Mol. Cell. 2001, 8 (2), 251-62.

(46) de la Cruz, J.; Kressler, D.; Linder, P. Unwinding RNA in Saccharomyces cerevisiae: DEAD-box proteins and related families. Trends Biochem. Sci. 1999, 24 (5), 192-8.

(47) Goshima, Y.; Nakamura, F.; Strittmatter, P.; Strittmatter, S. M. Collapsin-induced growth cone collapse mediated by an intracellular protein related to UNC-33. Nature 1995, 376 (6540), 50914.

(48) Inagaki, N.; Chihara, K.; Arimura, N.; Menager, C.; Kawano, Y.; Matsuo, N.; Nishimura, T.; Amano, M.; Kaibuchi, K. CRMP-2 induces axons in cultured hippocampal neurons. Nat. Neurosci. 2001, 4 (8), 781-2. 
(49) Kimura, T.; Watanabe, H.; Iwamatsu, A.; Kaibuchi, K. Tubulin and CRMP-2 complex is transported via Kinesin-1. J. Neurochem. 2005, 93 (6), 1371-82.

(50) Fukata, Y.; Itoh, T. J.; Kimura, T.; Menager, C.; Nishimura, T.; Shiromizu, T.; Watanabe, H.; Inagaki, N.; Iwamatsu, A.; Hotani, H.; Kaibuchi, K. CRMP-2 binds to tubulin heterodimers to promote microtubule assembly. Nat. Cell Biol. 2002, 4 (8), 58391.

(51) Fountoulakis, M.; Hardmaier, R.; Schuller, E.; Lubec, G. Differences in protein level between neonatal and adult brain. Electrophoresis 2000, 21 (3), 673-8.

(52) Eriani, G.; Delarue, M.; Poch, O.; Gangloff, J.; Moras, D. Partition of tRNA synthetases into two classes based on mutually exclusive sets of sequence motifs. Nature 1990, 347 (6289), 203-6.

(53) Preiser, J. C.; Zhang, H.; Vray, B.; Hrabak, A.; Vincent, J. L. Time course of inducible nitric oxide synthase activity following endotoxin administration in dogs. Nitric Oxide 2001, 5 (2), 20811.

(54) Mizobuchi, T.; Yagi, Y.; Mizuno, A.; Matsuzaki, H.; Matsuda, M. Increased tubulin messenger RNA in the frog retina after optic nerve transection. Neurosci. Lett. 1988, 86 (2), 144-6.

(55) Miller, F. D.; Naus, C. C.; Durand, M.; Bloom, F. E.; Milner, R. J. Isotypes of $\alpha$-tubulin are differentially regulated during neuronal maturation. J. Cell Biol. 1987, 105, (6 Pt 2), 3065-73.

(56) Bozanic, D.; Bocina, I.; Saraga-Babic, M. Involvement of cytoskelatal proteins and growth factor receptors during development of the human eye. Anat. Embryol. (Berlin) 2006.

(57) Sharma-Luthra, R.; Kale, R. K. Age related changes in the activity of the glyoxalase system. Mech. Ageing Dev. 1994, 73 (1), 39-45.

(58) Finger, F. P. One, ring to bind them. Septins and actin assembly. Dev. Cell. 2002, 3 (6), 761-3.

(59) Kinoshita, A.; Noda, M.; Kinoshita, M. Differential localization of septins in the mouse brain. J. Comp. Neurol. 2000, 428 (2), $223-39$.

(60) Kinoshita, M.; Noda, M. Roles of septins in the mammalian cytokinesis machinery. Cell Struct. Funct. 2001, 26 (6), 667-70.

(61) Kremer, B. E.; Haystead, T.; Macara, I. G. Mammalian septins regulate microtubule stability through interaction with the microtubule-binding protein MAP4. Mol. Biol. Cell. 2005, 16 (10), 4648-59.

(62) Lorke, D. E. Developmental characteristics of trisomy 19 mice. Acta Anat. (Basel) 1994, 150 (3), 159-69.

(63) Agudo, Garcillan, D.; Gomez-Esquer, F.; Diaz-Gil, G.; MartinezArribas, F.; Delcan, J.; Schneider, J.; Palomar, M. A.; Linares, R. Proteomic analysis of the Gallus gallus embryo at stage-29 of development. Proteomics 2005, 5 (18), 4946-57.

(64) DiMauro, S.; Miranda, A. F.; Sakoda, S.; Schon, E. A.; Servidei, S.; Shanske, S.; Zeviani, M. Metabolic myopathies. Am. J. Med. Genet. 1986, 25 (4), 635-51.
(65) Immenschuh, S.; Baumgart-Vogt, E. Peroxiredoxins, oxidative stress, and cell proliferation. Antioxid. Redox Signaling 2005, 7 (5-6), 768-77.

(66) Rhee, S. G.; Chae, H. Z.; Kim, K. Peroxiredoxins: a historical overview and speculative preview of novel mechanisms and emerging concepts in cell signaling. Free Radical Biol Med. 2005 , 38 (12), 1543-52.

(67) Neumann, C. A.; Krause, D. S.; Carman, C. V.; Das, S.; Dubey, D. P.; Abraham, J. L.; Bronson, R. T.; Fujiwara, Y.; Orkin, S. H.; Van, Etten, R. A. Essential role for the peroxiredoxin Prdx1 in erythrocyte antioxidant defence and tumour suppression. Nature $\mathbf{2 0 0 3}$, 424 (6948), 561-5.

(68) Fujikado, T.; Tsujikawa, K.; Tamura, M.; Hosohata, J.; Kawasaki, Y.; Tano, Y. Effect of a nitric oxide synthase inhibitor on lensinduced myopia. Ophthalmic Res. 2001, 33 (2), 75-9.

(69) Lampi, K. J.; Shih, M.; Ueda, Y.; Shearer, T. R.; David, L. L. Lens proteomics: analysis of rat crystallin sequences and twodimensional electrophoresis map. Invest. Ophthalmol. Visual Sci. 2002, 43 (1), 216-24.

(70) Ying, W.; Hao, Y.; Zhang, Y.; Peng, W.; Qin, E.; Cai, Y.; Wei, K.; Wang, J.; Chang, G.; Sun, W.; Dai, S.; Li, X.; Zhu, Y.; Li, J.; Wu, S.; Guo, L.; Dai, J.; Wang, J.; Wan, P.; Chen, T.; Du, C.; Li, D.; Wan, J.; Kuai, X.; Li, W.; Shi, R.; Wei, H.; Cao, C.; Yu, M.; Liu, H.; Dong, F.; Wang, D.; Zhang, X.; Qian, X.; Zhu, Q.; He, F. Proteomic analysis on structural proteins of Severe Acute Respiratory Syndrome coronavirus. Proteomics 2004, 4 (2), 492-504.

(71) Choi, M. H.; Lee, I. K.; Kim, G. W.; Kim, B. U.; Han, Y. H.; Yu, D. Y.; Park, H. S.; Kim, K. Y.; Lee, J. S.; Choi, C.; Bae, Y. S.; Lee, B. I.; Rhee, S. G.; Kang, S. W. Regulation of PDGF signaling and vascular remodelling by peroxiredoxin II. Nature 2005, 435 (7040), 34753.

(72) Lam, C.; Li, K. K.; Lo, S. C. L.; To, C. H. Differential protein expressions in the emmetropization of chick retina by a proteomic approach. Invest. Ophthalmol. Visual Sci. 2005, 46, (5), 3144

(73) Zhou, G.; Li, H.; DeCamp, D.; Chen, S.; Shu, H.; Gong, Y.; Flaig M.; Gillespie, J. W.; Hu, N.; Taylor, P. R.; Emmert-Buck, M. R. Liotta, L. A.; Petricoin, E. F. 3rd; Zhao, Y. 2D differential in-gel electrophoresis for the identification of esophageal scans cell cancer-specific protein markers. Mol. Cell. Proteomics 2002, 1 (2), 117-24.

(74) Fujii, K.; Kondo, T.; Yokoo, H.; Yamada, T.; Iwatsuki, K.; Hirohashi, S. Proteomic study of human hepatocellular carcinoma using two-dimensional difference gel electrophoresis with saturation cysteine dye. Proteomics 2005, 5 (5), 1411-22.

PR0701097 